Journal of Association of Arab Universities for Tourism and Hospitality Vol. 10 No.2, (2013)
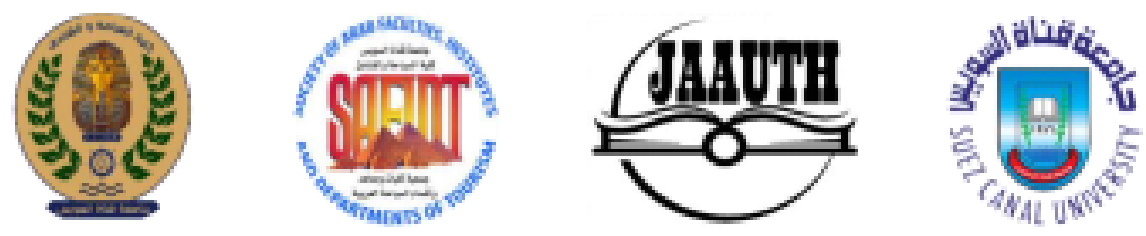

Journal of Association of Arab Universities for Tourism and Hospitality (JAAUTH)

(ISSN-O: 2682-4612 - ISSN-P: 1687-1863).

https://jaauth.journals.ek6.eg/ 


\title{
تأثير ظاهرة التسول على صناعة السياحة في مصر
}

\author{
إبر اهيم أحمد أحمد حمودة
}

مدرس بقسم الأراسات السياحية، كلية المسياحة والفنادق، جامعة حلوان

الملخص

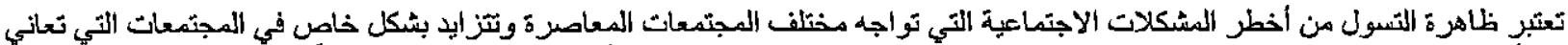

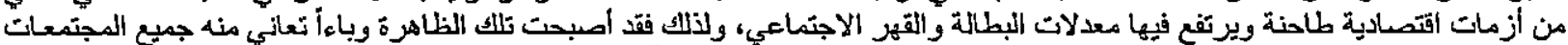

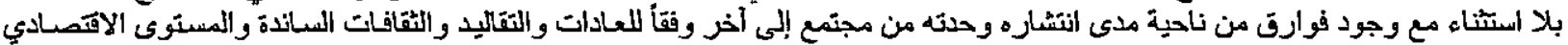

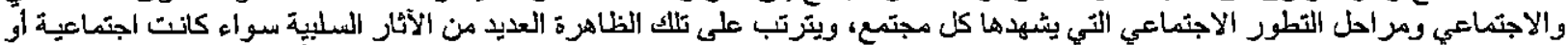

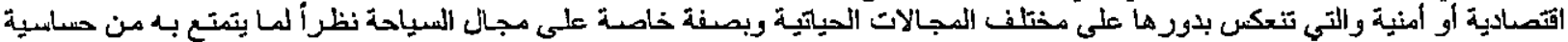

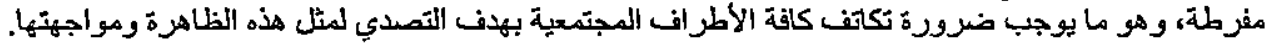

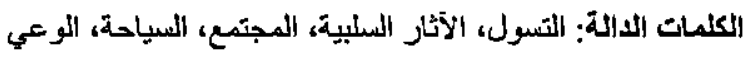

\section{مثكلة الازاسة}

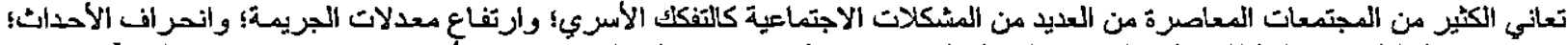

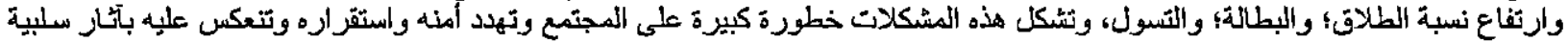

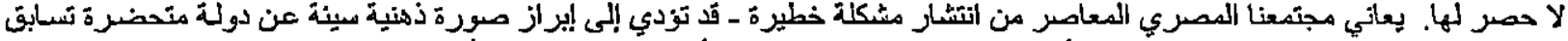

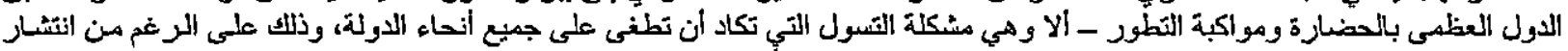

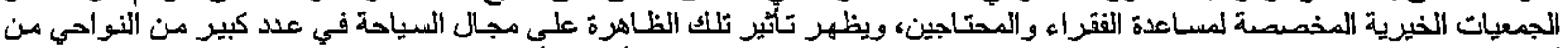

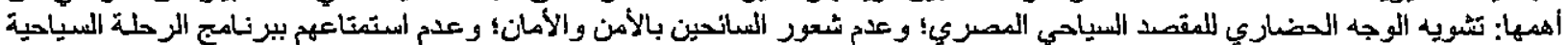

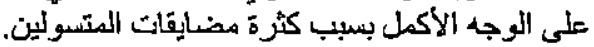

أهمية الدراسة

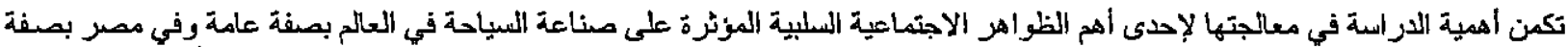

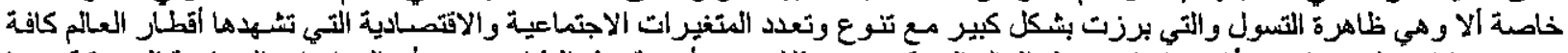

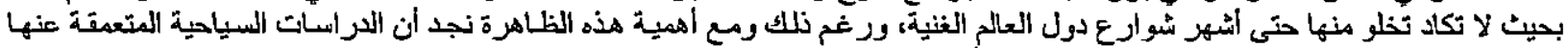

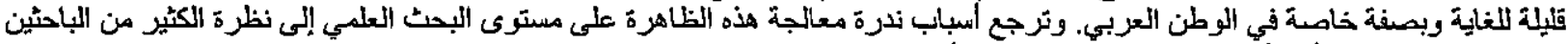

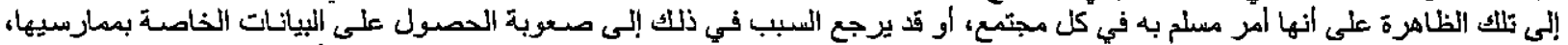

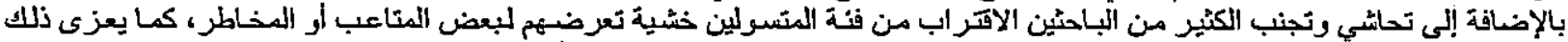

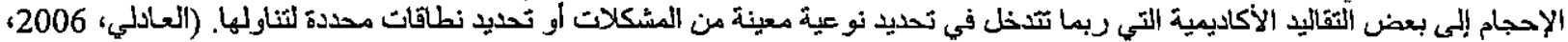

تثمثل أهداف هذه الدر استة في النقاط التالية: 1. إلقاء الضوء على ماهية وأسباب ظاهزة التسول. 2. تشخيص الآثار السلبية المترثبة على طاهرة التسول.

3. التحرن على موقف الإسلام من ظاهرة التسول.

4. الموقوف على كيفية تناول ظاهرة التسول في القو اننين الموضعبة.

5. تحليل مدى خطورة ظلاهرة التسول على صناعة السياحة.

6. تحديد مظاهر وأسباب انخفاض مستوى الوعي السياحي كاحد الأسباب الموّدية إلى انتشار ظاهزة التسول في مختلف الدول السياحية. 7. تقديم بعض المقرحات و التوصيات التي من شانها التصدي التلك الظلاهرة.

فرض الدراسة

إن انتثار ظلاهرة التسول في الكثير من المناطق السمياحية في مصر سينعكس بصسورة سلبية على مدى تردد الساتحين على المقصد السياحي المصري على المدى البعيد. 


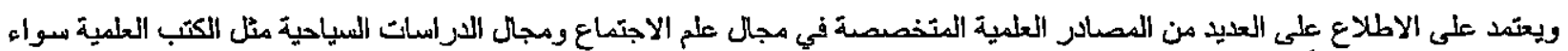

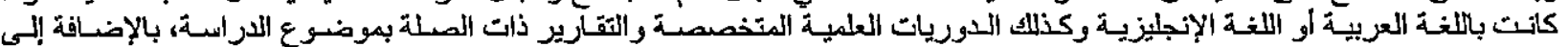
المؤتمرات والترساثل العلمية والنشرات ومواقع الانترنت

الاراسة الميدانية

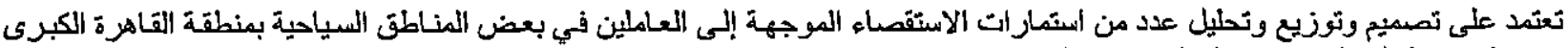

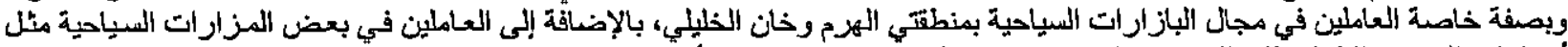

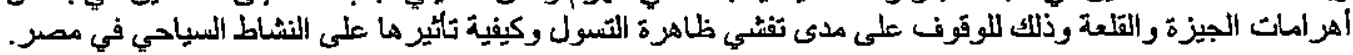

الاراسات السابتة

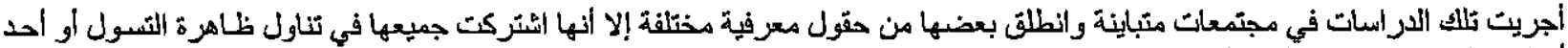

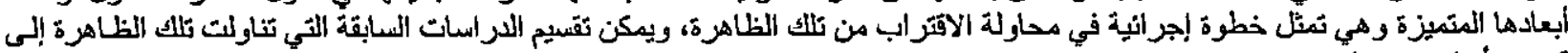
قسمين أساسيين هما:

1. الار اسات الخاصة بالمجنمعات الغربية ولعل أهمها:

أ- دراسة (Steven P. Segal, 1977) وآخرون الأصابة بالجنون: الاضطراب العقلي والهامتية الاجتماعية للشباب المتشرد'.

ب- دراسة (Ellen L. Bassuk, 1984) وآخرون'هل المئردون مشكلة صحية عقلية'. ج- دراسة (George Gmelch, 1978) وآخرون 'الآتسول في دبلن: استراتيجية المهنة الهامشية الحضرية'.

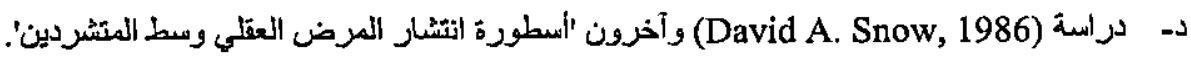
2. دراسات التصول في المجتمعات العربية والمجتمع المصري ورلعل أهدها: أ- دراسة (حامد زهران، 1985) "التسول دراسة نفسية استطلاعية'.

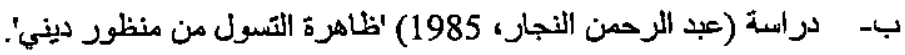

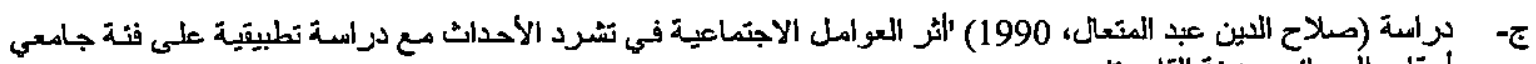
أعقاب السجانز بمدينة القاهرة'.

دـ دراسة (محمود إير اهيم حسين، 1983) 'دراسة انثزوبولوجية تطبيقية للانساق والعلاقات في مجتمع المتسولين بالإسكندرية'. الإطار النظري للاراسة

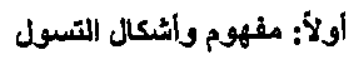

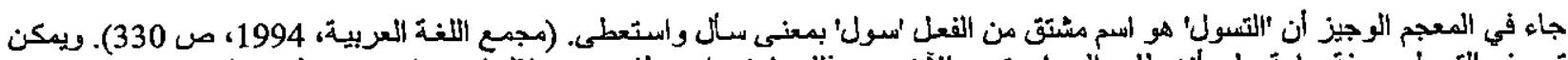

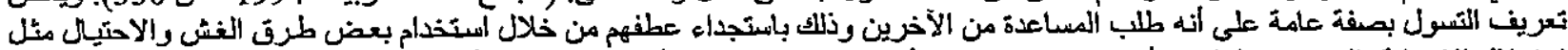

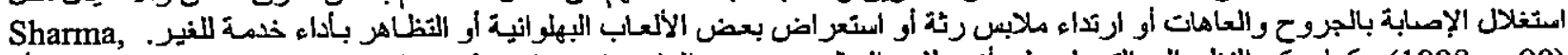
(1998, p.90)

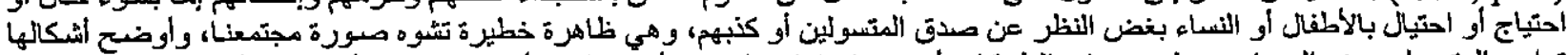

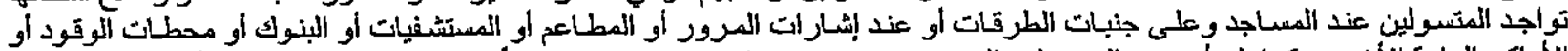

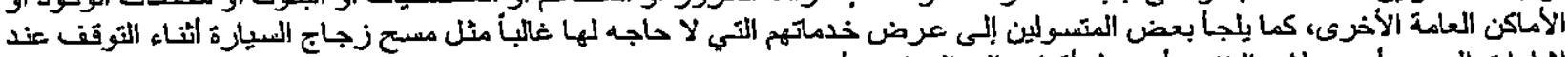

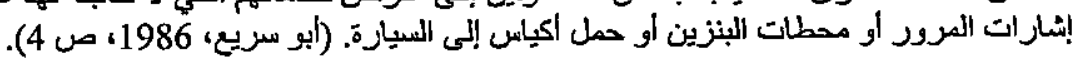

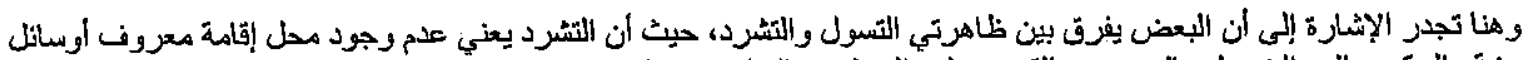

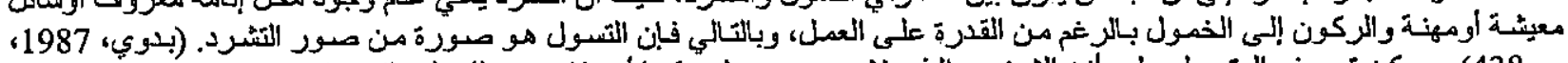

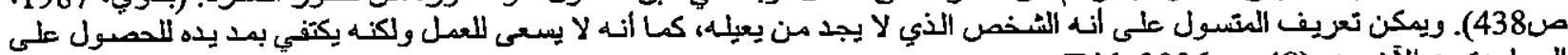

المساعدة من الآخرين. (Bid, 2006, p. 48)

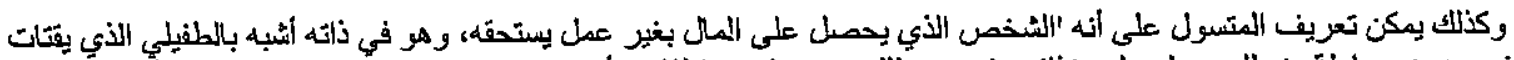

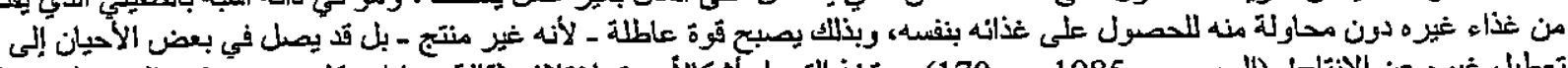

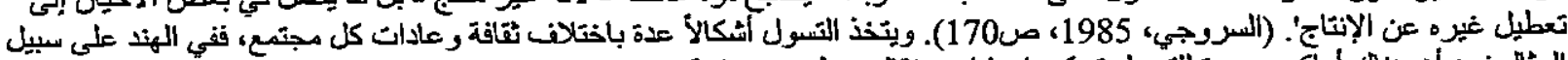

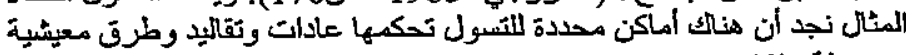

معروفة. (Parashar, 2003, p. 48) 


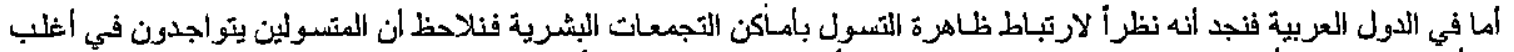

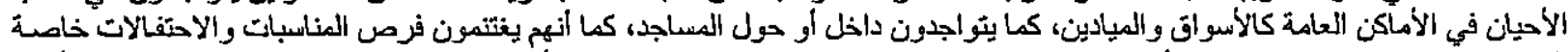

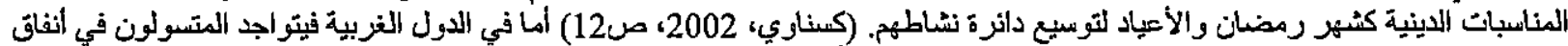

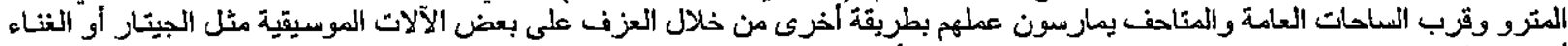

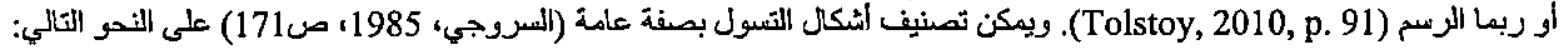
1. تسول ظاهر: وهو التسول المواضح الصربح المعلن وفيه يمد المتسول يده مستجدياً المناس.

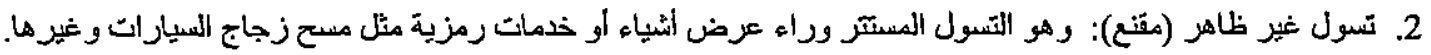

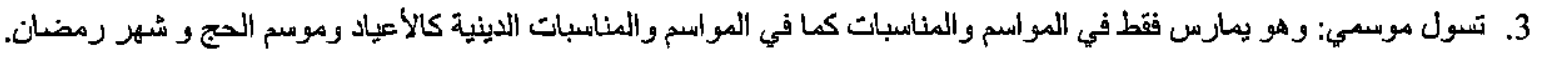

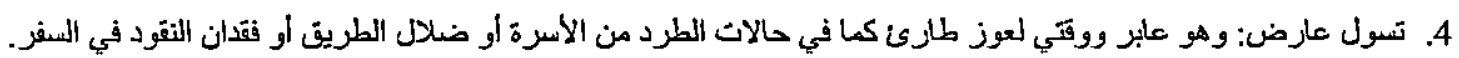

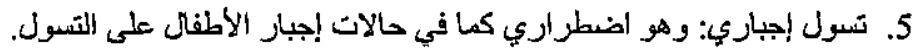
6. تسول الختياري: حيث الانحر اف والجري وراء الفياء الكسب.

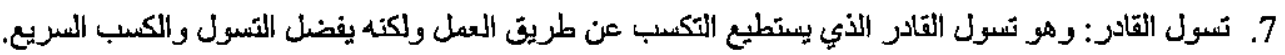
8. تسول غير القادر: وهو تسول العاجز أو المريض عتلياً. 9. تسول الجانع: حيث يكون التسول مصاحبأ بالجنوح والإجرام حيث لا بأس إلى جانب ممارسة مهنة التسول من قيام المتسول بالسرقة أو النظطل. ثانياً: أسباب ودوافع التصول

تشير معظم الارأسات إلمى أن الأسباب الرئيسية لانتشار ظاهرة التسول هي الفقز والبطالة، بالإضافة إلى قصور آداء أنظمة اللرعاية الاجتماعية لذوي الاحتياجات الخاصة مثل الصم والبكم والمقعدين. (Madan, 2003, p. 82)

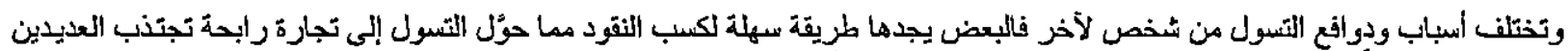

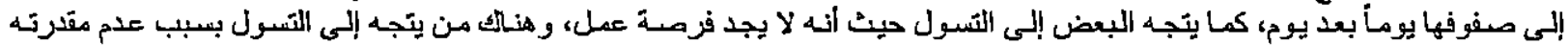
على العمل.

وبصفة عامة يمكن تصنيف أسباب التسول (http://www.aleqet.com, 2007) على النحو التَالي:

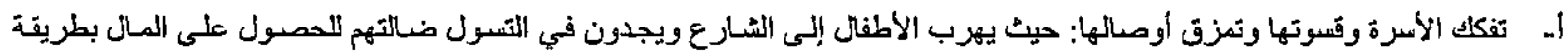
سهلة لتحقيق مطالبهم.

بـ الفقر: يعتبر الفقز الحد أهم أسباب التسول حيث تدفع الحاجة بعض الأطفـل أو النسـاء أو الزجال إلى امتهبان التشبول كوسيلة لتعويض

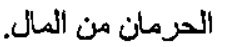

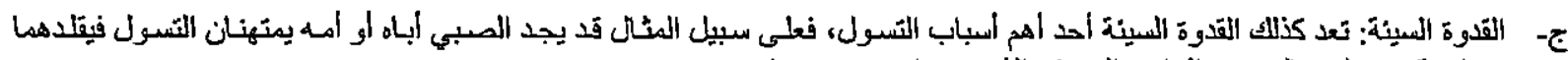
وخاصة مع تلمه بالمردود المادي المرتفع الذي يجنياه المنياه من مهنتها.

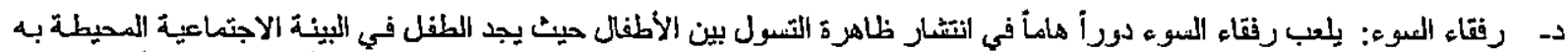

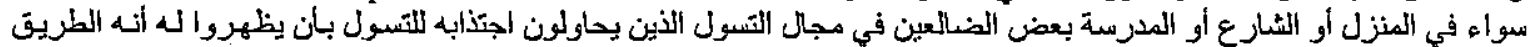

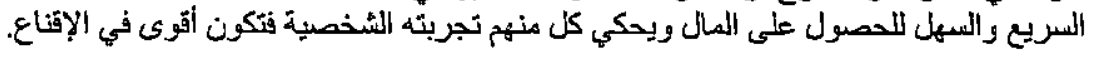

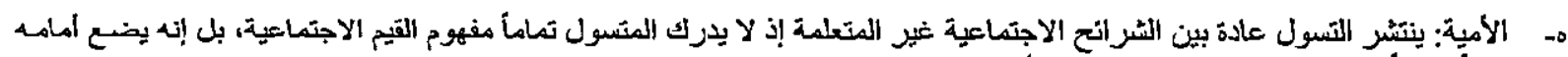

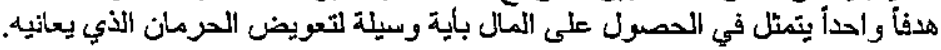

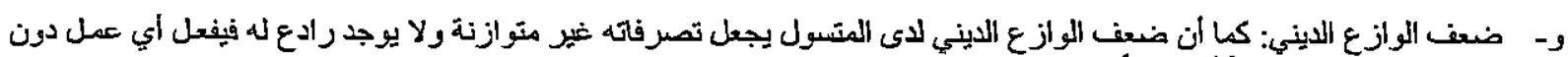
البحث عما إذا كان حلالا أم حرامأ.

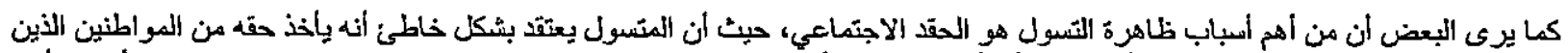

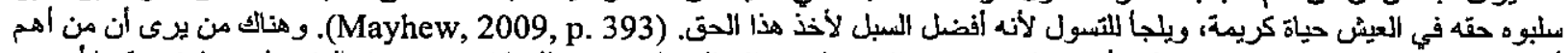

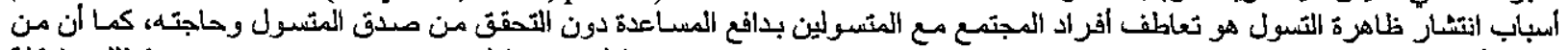

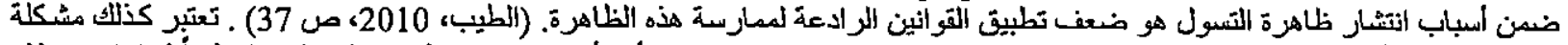

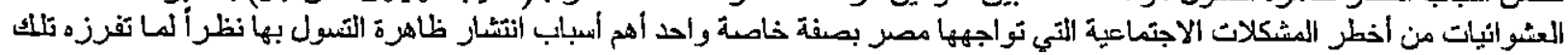
العشو انيات من المئات من المتنسولين.

ناثائاً: التسول من منظور إسلامي

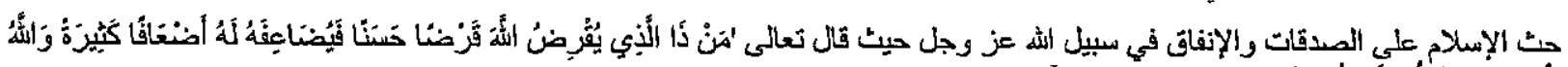

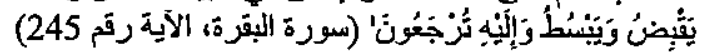




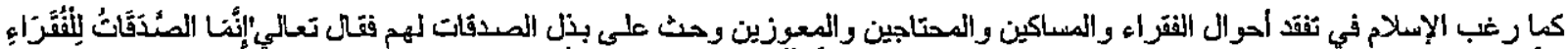

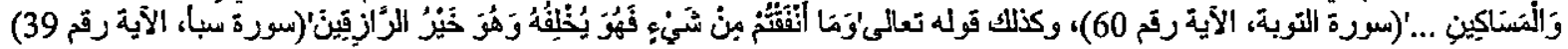

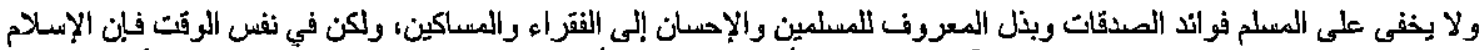

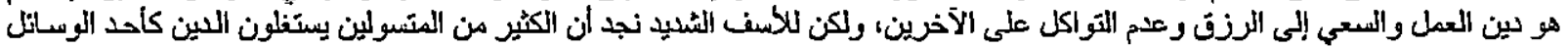

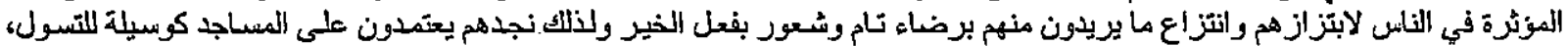

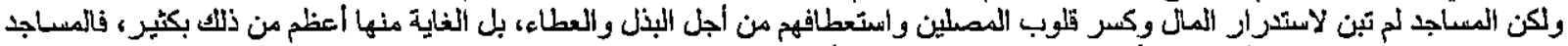

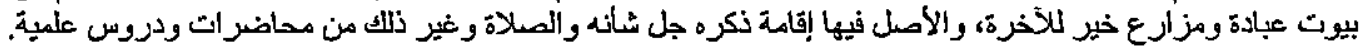

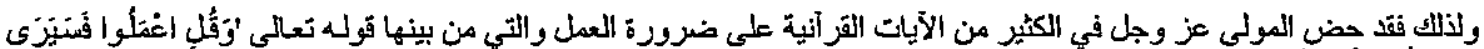

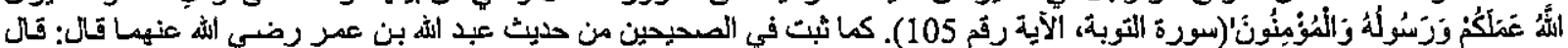

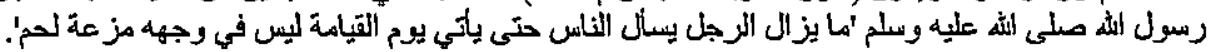

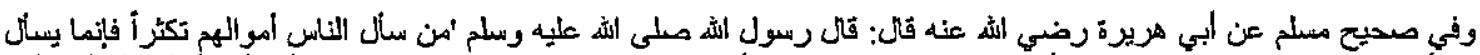

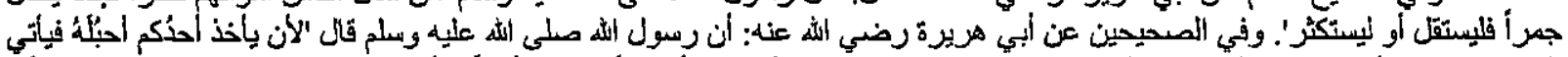

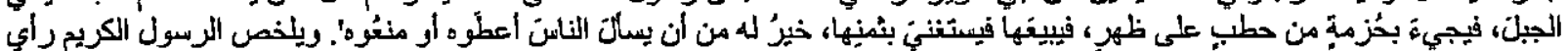

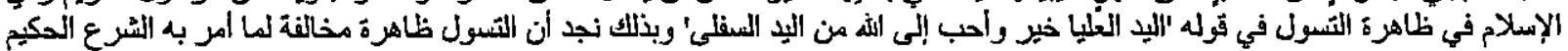

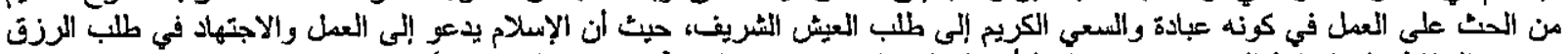

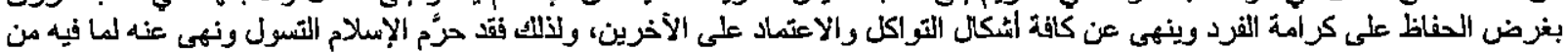

الأل والمهانة.

\section{رابعأ: التسول في التوانين الموضعية المعاصرة}

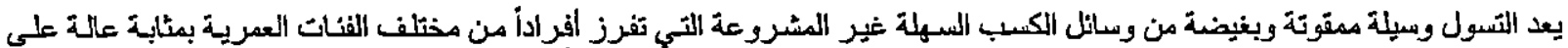

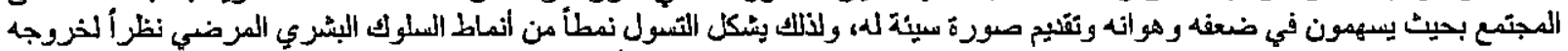

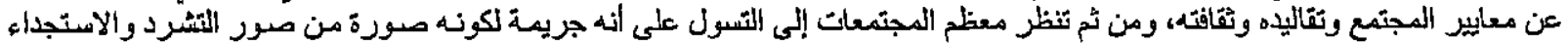
ووسيلة شير مشروعة اللعيش.

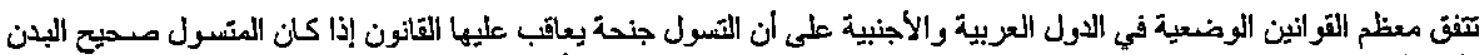

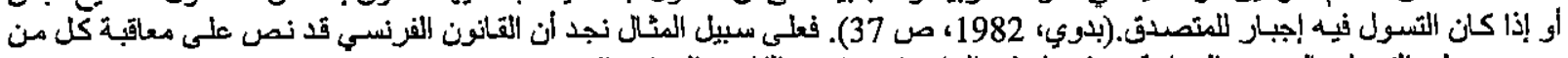

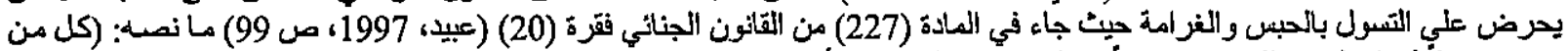

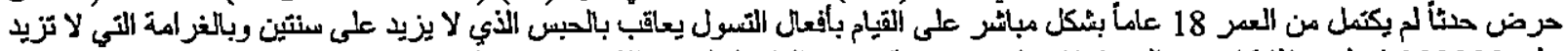

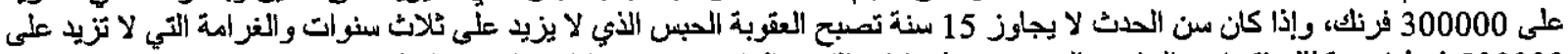

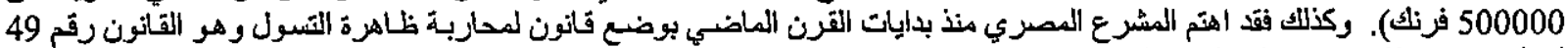

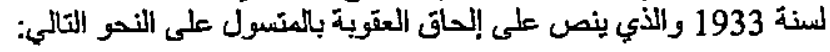

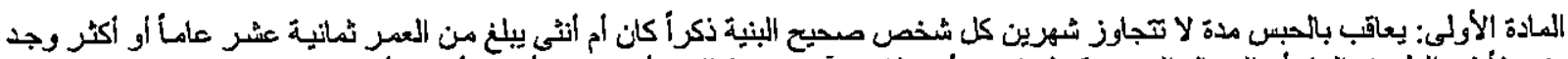

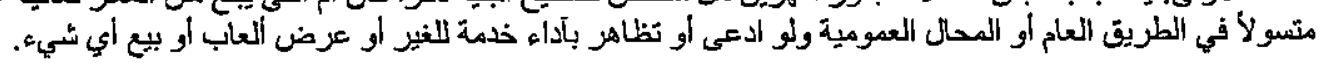

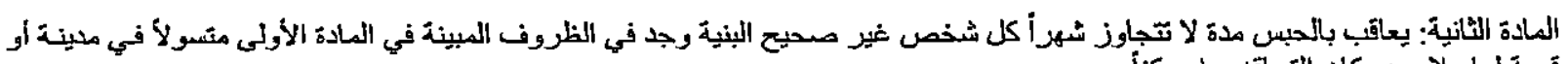
قرية لها ملاجئ وكان التحاقه بها ممكناً.

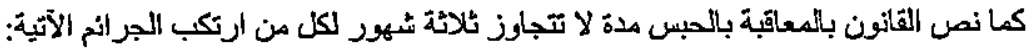

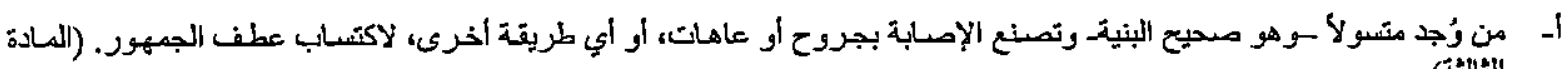

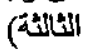

ب- من دخل منزلاً او ملحقاً بدون إنن ويقصد التسول. (المادة الرابعة)

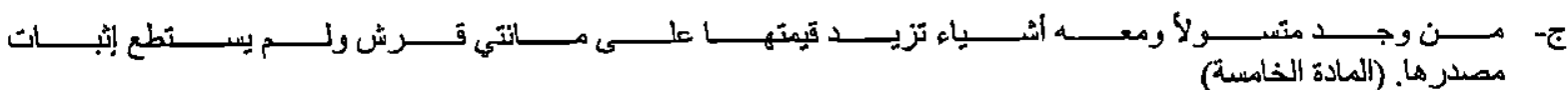

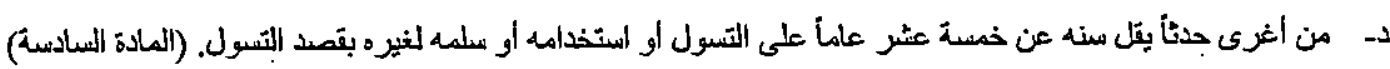

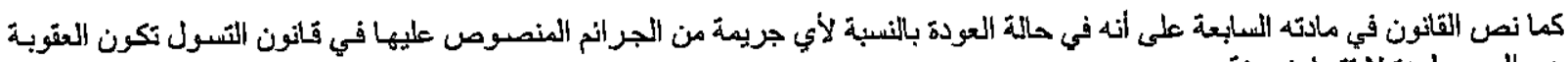
هي الحبس لمدة لاتثجاوز سنة.

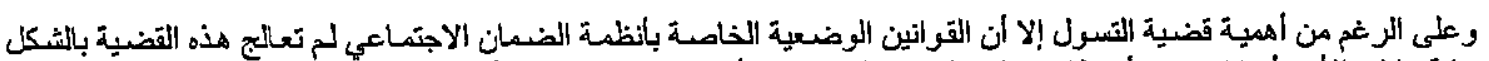

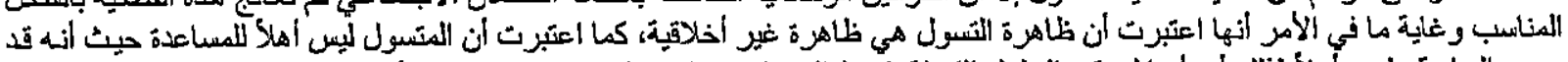

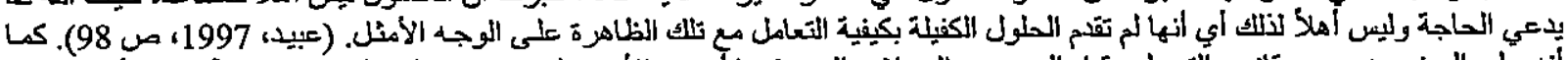

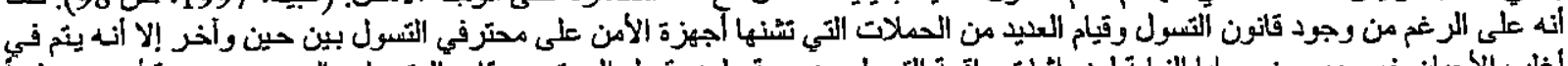

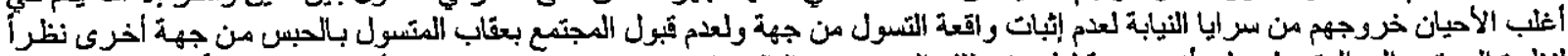

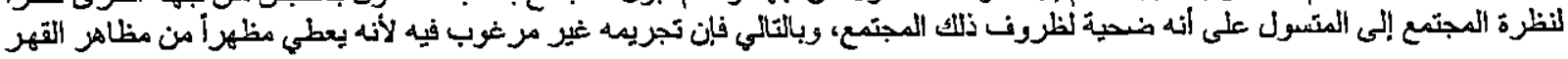


القانوني لثخص في ظروف صسبة، وبالتالي فالمطلوب هو توفير عمل له بتعليمه ور عايته اجتماعياً وصحياً ودراسـة ظروفه رمعرفة سبب

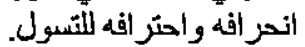

\section{خامسأ: تاثئير ظاهرة التسول على القرد والمجتمع}

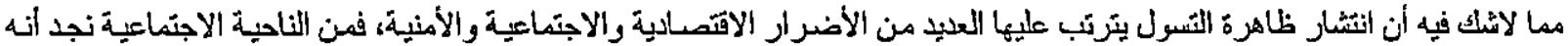

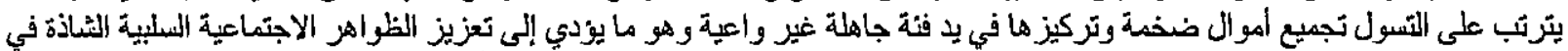

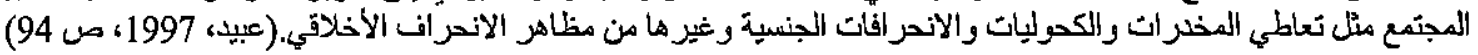

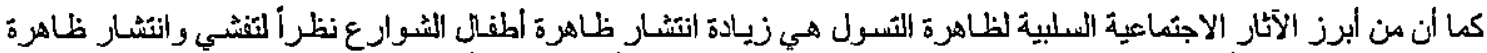

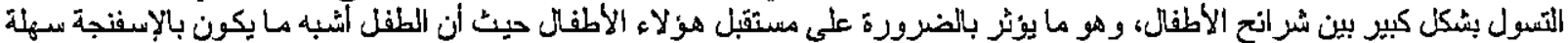

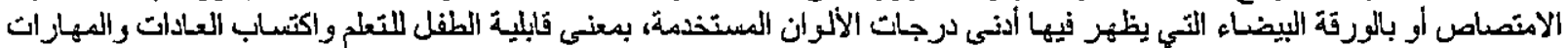

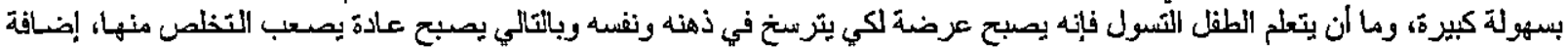

إلى الآثار النفسية التي يصعب التخلص منها في شخصية الفرد وسلوكه. (Goyal, 2005, p. 167)

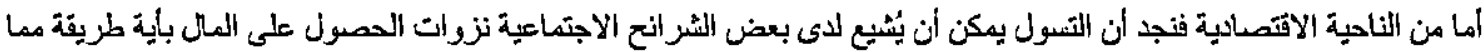

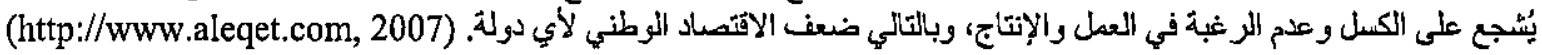

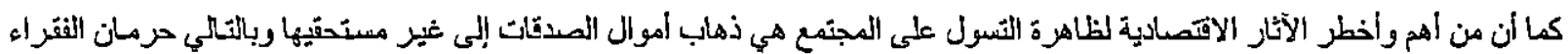

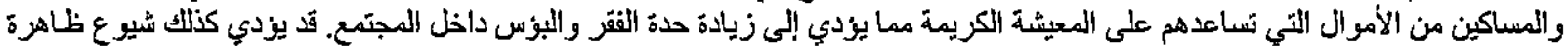

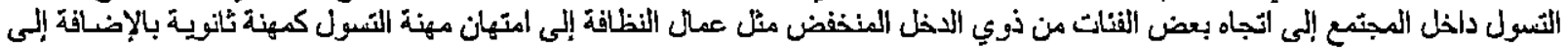

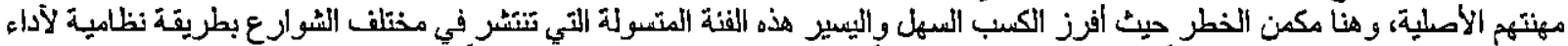

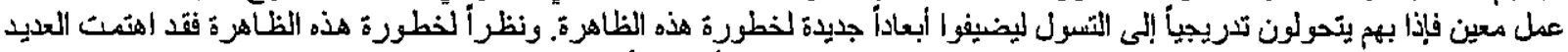

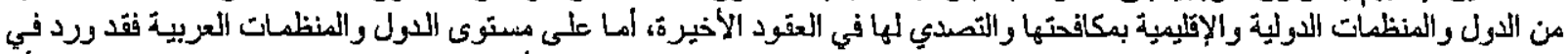

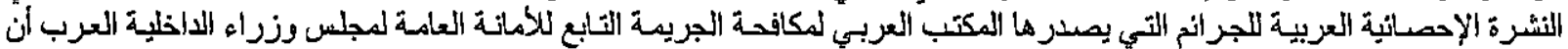

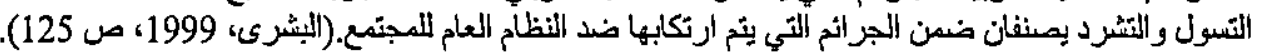

سادسأ: خطورة التسول على النشاط السباحي

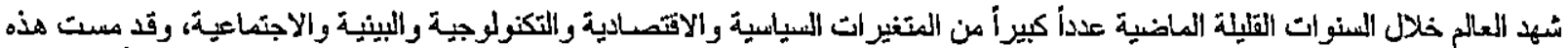

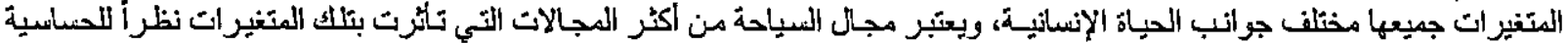

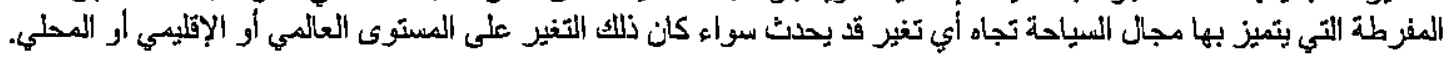

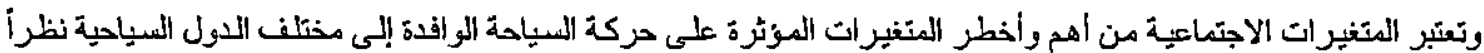

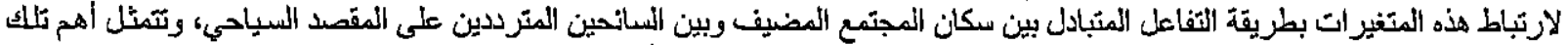

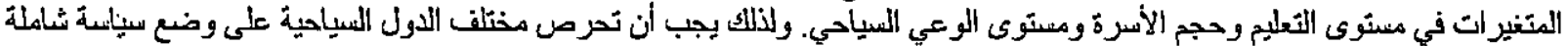

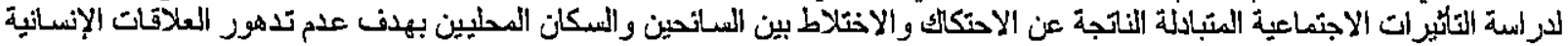

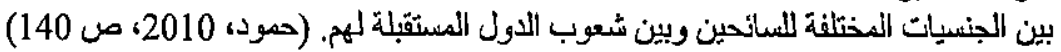

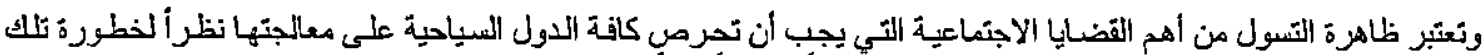

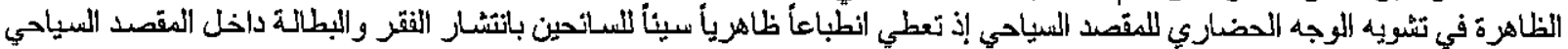

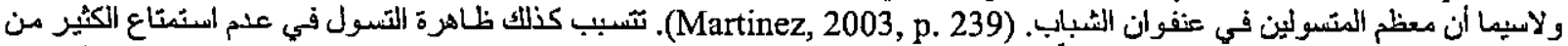

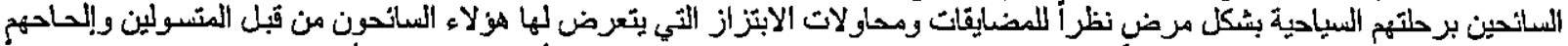

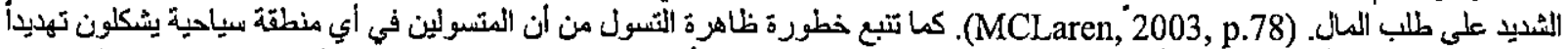

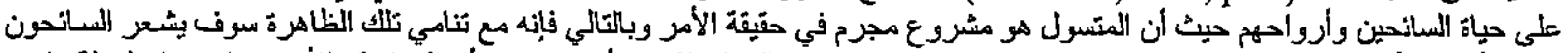

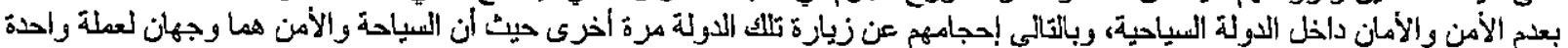

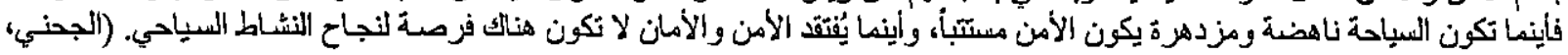

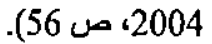

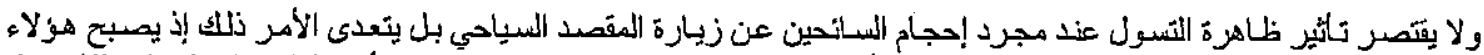

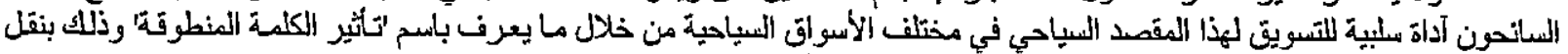

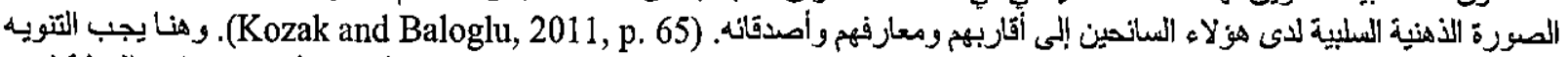

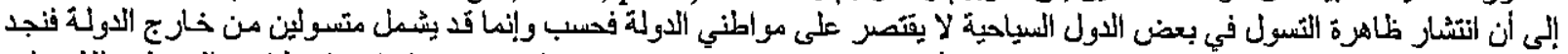

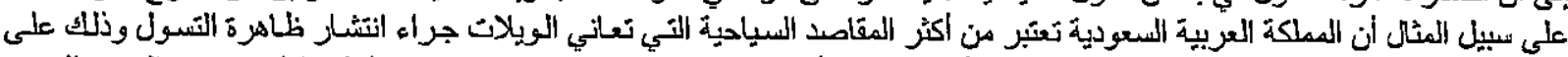

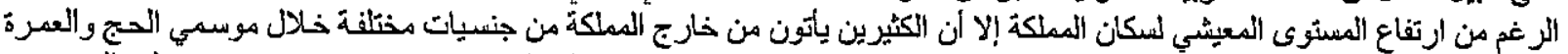

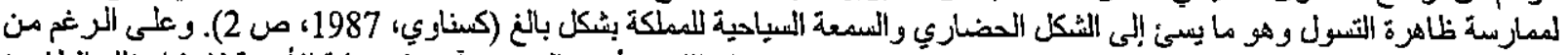

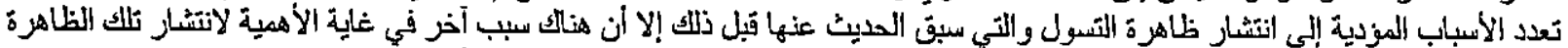

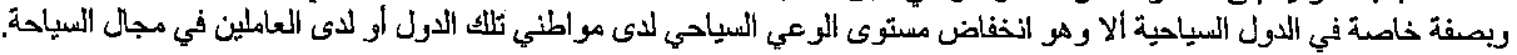


سابعأ: مظاهز واسبباب انغفاض مستوى الوعي اللسياحي

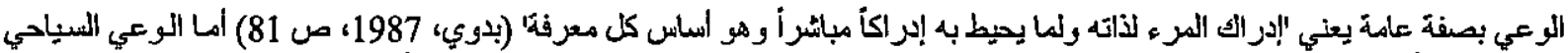

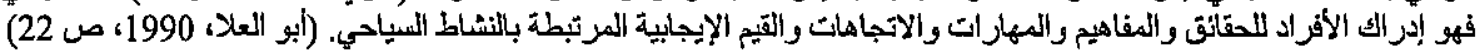
وتكمن أهمية الوعي السياحي (لطيف وخطيري، 2005، ص 63) بصفة عامة في الثقاط التالية: 1. وسيلة النتقيف وتعريف أفراد المجتمع بأهمية النشاط السياحي.

2. تنبيه أفراد المجتمع إلى خطورة المشكلات التي تواجه النثاط السياحي وتقليم معترحات لكيفية حلها.

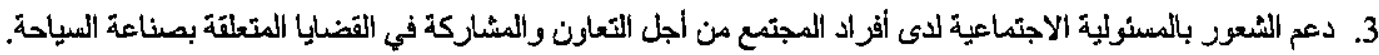

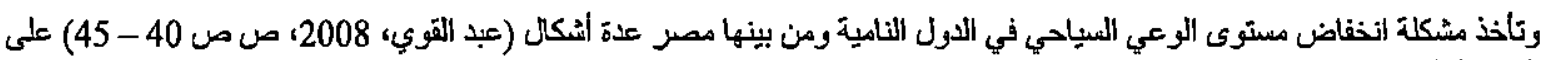
النحو التالمي: أ. عدم وجود وعي سيامي وديني صحيح بين أفراد المجتمع لتتوضيح مدى أهمية السياحة كمصدر ددر للاخل وكذلك توضيح حقيقة اللين وتعاليهه السحة التي تحرم القتل والتخريب. ب. نثُوب بعض المشاجرات بين العاملين في المناطق الأئرية وبين المرشّدين السياحيين أمام الافوراج السياحية تتيجة لعدم معرفتهم بفن

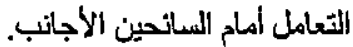

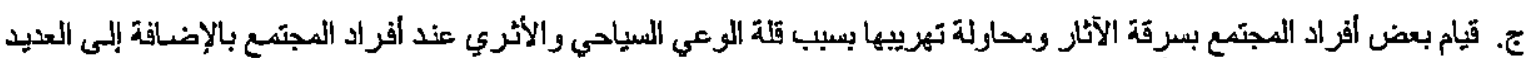

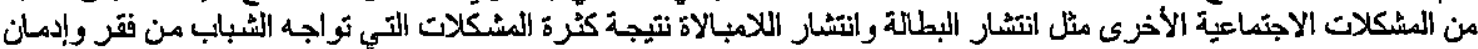
وعنوسة وعدم رجود شتقن سكنية.

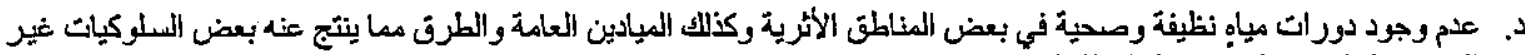
الحضارية التي لا تليق بمكانة الدولة السياحية.

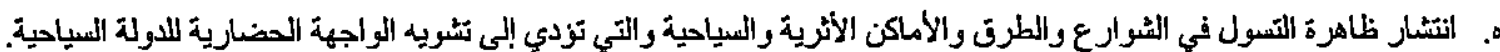
و. قيام بعض الشباب بيعض اللتصرفات المشينة مثل مضايقة الساتحات الأجنبيات.

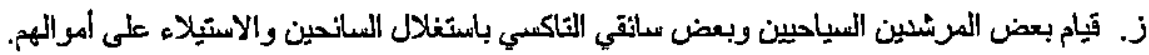

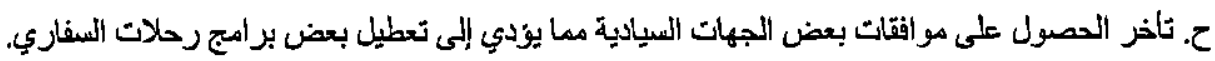
ط. عم وجود طرق ممهدة للوصول إلى بعض المناطق السياحية والأثرية، كما أن هذه الطرق خالية من اللوحات الإرشادية والإضاءة.

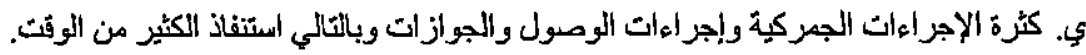

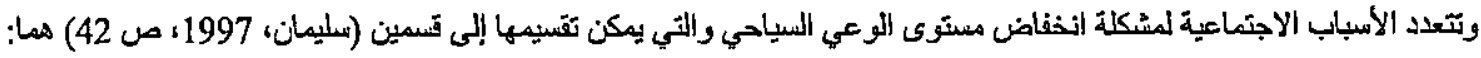
1. أسباب مثعقة بالمكان المحليين وتثمثل فيما يلي:

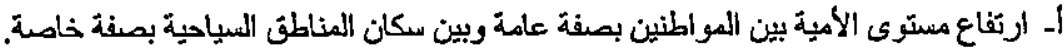
بـ انتشار الفقر والبطالة بين سكان المناطق السياحية. ج- اختلاف الثقافات بين العاتحين و المواطنين المطانيين. د- صعوية تفاهم السكان المحليين مع المانحين الأجانب لعدم وجود لغة مُّتركة.

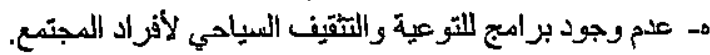
2. أسباب متعلقة بالعاملين في مجال السياحة وبتمثل في النقاط الثلالية:

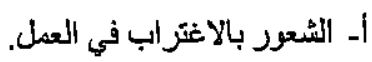

ب- عدم وجود دورات أو برامج ثقيقيةية للعاملين في مجال السياحة.

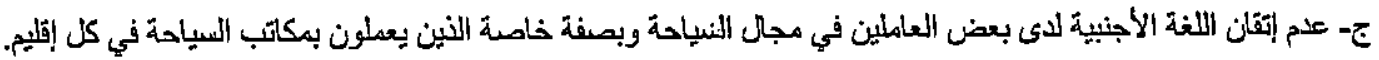

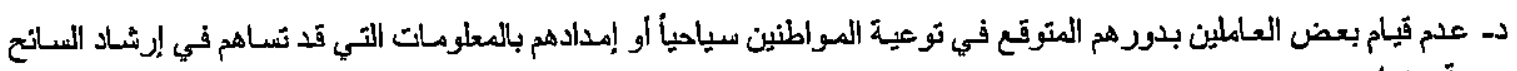
وتوجيهـ.

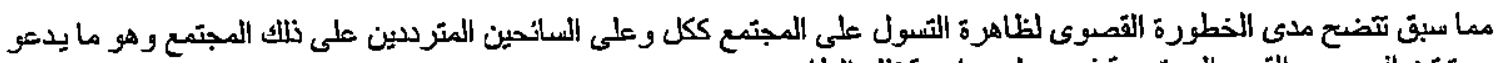
إلى ضرورة تضافر جميع القوى المجنمعية في سبيل مواجهة تلك الظكاهرة. 
الاراسة الميدانية

أولأ: مجتمع وعينة الدراسة

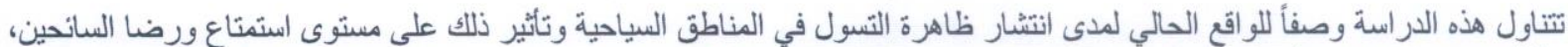

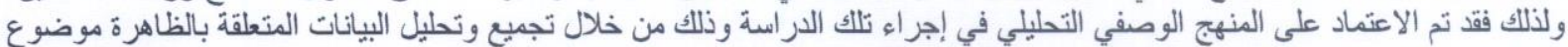

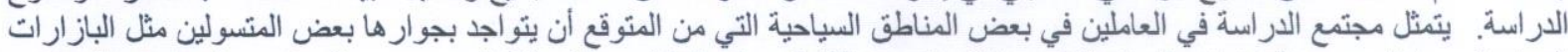

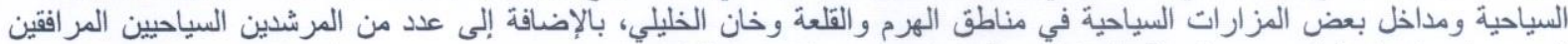

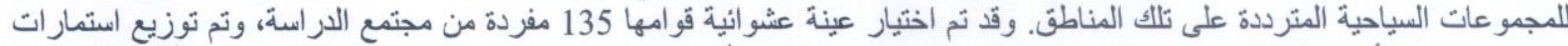

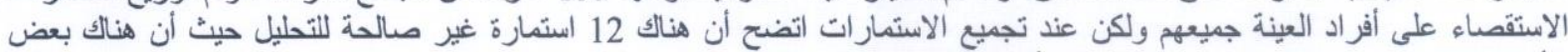

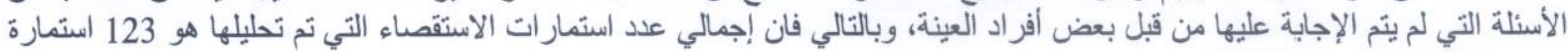

و هو ما يمثل إجمالي حجم العينة.

ثانيأ: الأسلوب الإحصائي المستخدم في تحليل استمارات الاستقصاء

اختبار ات صدق وثبات المقياس الاسل

بتطبيق وإجر اء اختبار ات الصدق واتبات الثبات لبيان معامل الثبات الخاص بالعينة فقد تبين الآتي:

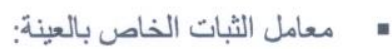
و عددها 123 مفردة =0.970 ، أى يساوى 97\% وهو هو معامل ثبات مرتفع.

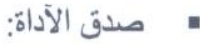

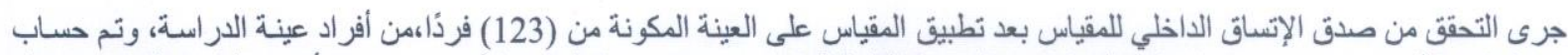

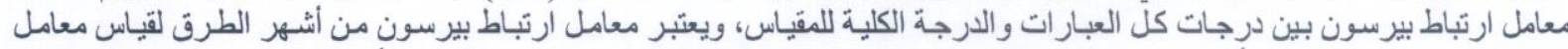

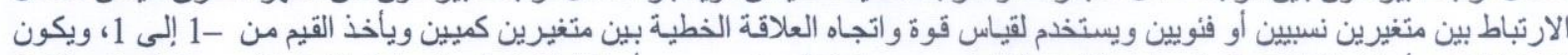

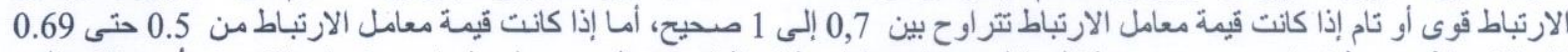

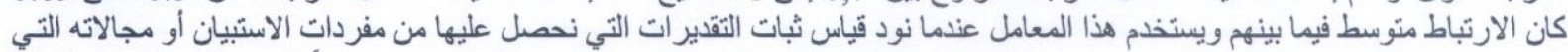

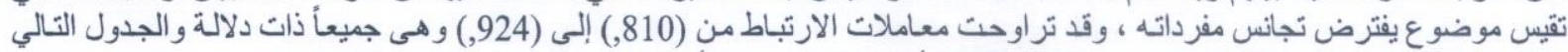
يوضح علاقة الإرتباط بين كل عبارة ومجموع العبار ات الأخرى الواردة الاردي في الأسئلة التي جاءت في في استمارة الاستقصاء.

والجدول الثالي يوضح ذللك باستخدام البرنامج الإحصائي (SPSS)

جدول 1: معاملات الارتباط بين درجات مجالات المقياس والدرجة الكلية للمقياس

\begin{tabular}{|c|c|c|c|}
\hline مستوي & قالارتباط معامل & الأبعـاد & b., \\
\hline 0.000 & $.883 * *$ & مدى تو اجد المتسولين قرب المناطق السياحية & .1 \\
\hline 0.000 & $.916^{* *}$ & الكثر الفنات التي تمـارس مهنـة التسول في المناطق & .2 \\
\hline 0.000 & $.822 * *$ & طلب المال & .3 \\
\hline 0.000 & $.888^{* *}$ & بيع أشباء تافهة & .4 \\
\hline 0.000 & $.850 * *$ & إيراز العاهات & .5 \\
\hline 0.000 & $.920 * *$ & ردود أفعال السائحين تجاه المتسولين & .6 \\
\hline 0.000 & $.873 * *$ & مدى شعور السائحين بالامان في ظل انتشار ظاهرة & .7 \\
\hline 0.000 & $.924 * *$ & 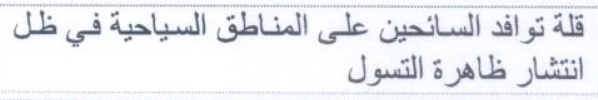 & .8 \\
\hline 0.000 & $.878^{* *}$ & التسول قيام شرطة السياحة بدور ها في مواجهة ظاهرة & .9 \\
\hline 0.000 & $.840 * *$ & وعي أفراد المجتمع بمدى خطورة ظاهرة التسول & .10 \\
\hline 0.000 & $.810^{* *}$ & 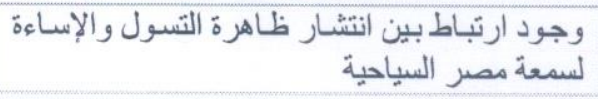 & .11 \\
\hline 0.000 & $.890 * *$ & التو عية الإعلامية & .12 \\
\hline 0.000 & $.822 * *$ & تفعيل دور شرطة السياحة & .13 \\
\hline
\end{tabular}




\begin{tabular}{|c|c|c|c|}
\hline الدالدوي & 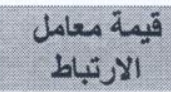 & الأبعـاد & +.J \\
\hline 0.000 & $.832 * *$ & وضع قو انين زاجرة للحد من تلك الظاهرة & .14 \\
\hline 0.000 & $.861 * *$ & لريـام وزارة المتسولين الثُون الاجتماعيـة بوضـع خطـة شـاملة & .15 \\
\hline 0.000 & $.888 * *$ & 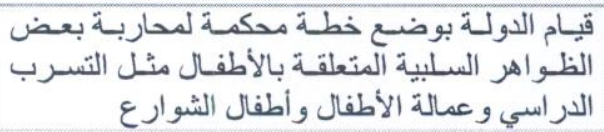 & .16 \\
\hline
\end{tabular}

يتضح من الجدول رقم (1) أن هناك ارتباطاً إيجابياً قوي بين الأبعاد والمقياس ككل، مما يدلل على صدق المقياس في قياس ما وضع لأجله.

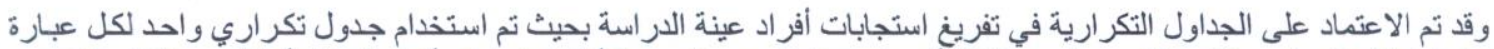

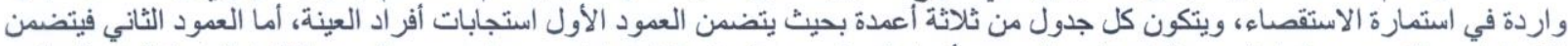

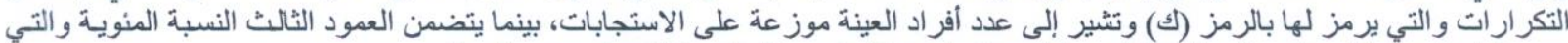
يرمز لها بالرمز (\%) وتشير إلى النسبة المنوية لعدد تكرارات كل استجابة بالنسبة لإجمالي حجم العينة.

ثالثأ: تحليل استمارات الاستقصاء

إشتملت استمارة الاستقصاء التي تم توزيعها علي مجتمع الدر اسة السالف ذكره على عشرة أسنلة استهدفت تحقيق أهداف الدر اسة وإثبات صحة الفرض الذي ذهبت إليه الدراسةً، وقد كانت الاستجابات علي علي هذه الأسئلة علي النحو التالي: السؤال الأول بصفتك أحد العاملين في مجال السياحة، هل تلاحظ تو اجد بعض المتسولين قرب منطقة عملك؟
أحياناً ( )
( ) ע
( ) نعم (1)

يوضح الجدول رقم (2) استجابات أفر اد العينة فيما يتعلق بتو اجد أو عدم تواجد بعض المتسولين قرب المناطق السياحية.

جدول 2: تواجد المتسولين قرب المناطق السياحية

\begin{tabular}{|c|c|c|}
\hline النسبة المنوية (\%) & التكرار (ك) & الاستجابات \\
\hline 71.5 & 88 & نعم \\
\hline- & $\longrightarrow$ & ע \\
\hline 28.5 & 35 & أحياناً \\
\hline 100 & 123 & الإجمالي \\
\hline
\end{tabular}

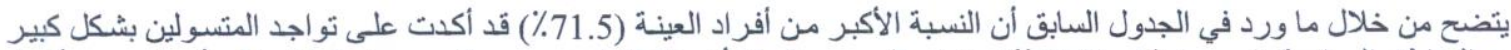

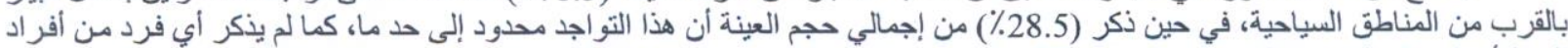

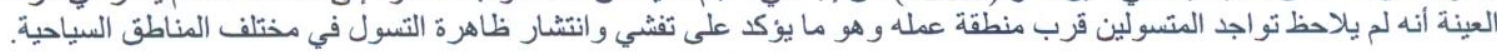

السؤال الثاني إذا كانت الإجابة في السؤال السابق بـ (نعم) أو (أحيانأ) فما هي أكثر الفنات التي تمارس مهنة التسول؟
( ) ( المسنين (1)

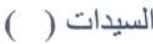
( ) الشباب (1)

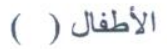

يوضح الجدول رقم (3) استجابات أفراد العينة المتعلقة بأكثر الفئات التي تمارس مهنة التسول.

\section{جدول 3: أكثر الفئات التي تمارس مهنة التسول في المناطق السياحية}

\begin{tabular}{|c|c|c|}
\hline النسبة المئوية (\%) & التكرار (ك) & الاستجابات \\
\hline 41,4 & 51 & الأطفال \\
\hline 11,4 & 14 & الشباب \\
\hline 36,6 & 45 & السيدات \\
\hline 10,6 & 13 & المسنين \\
\hline 100 & 123 & الإجمالي \\
\hline
\end{tabular}


تأثير ظاهرة التسول على صناعة السياحة في مصر

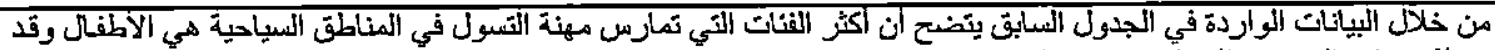

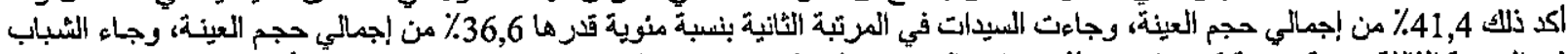

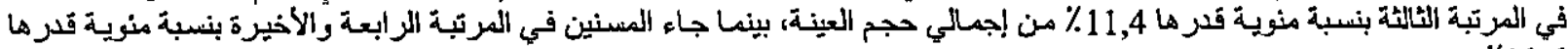

السؤال الثالث

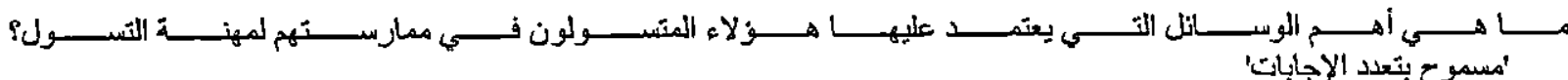
( ) إيراز العاهات ( )
( ) بيع الشياء تافهة (1)

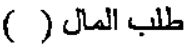

وسائل أخرى (يرجى ذكرها)

يوضح الجدول رقم (4) استجابات افراد العينة فيما يتعلق بالطرق والأساليب التي يعتمد عليها المتسولين في تسولهم بالمناطق العياحية.

جدول 4: أساليب التسبول في المناطقى السياحية

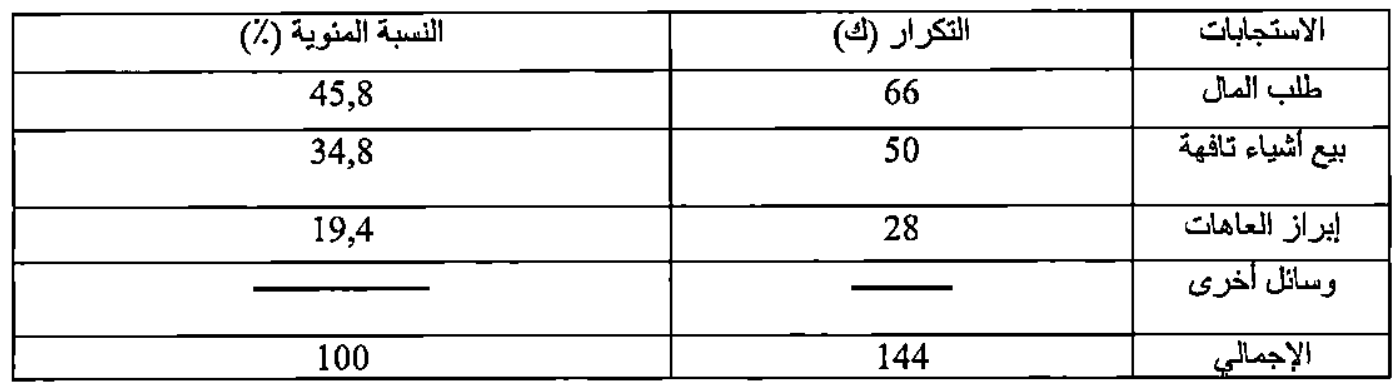

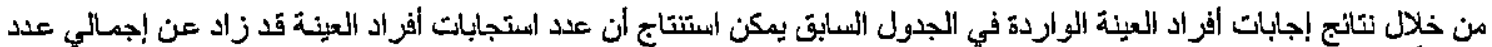

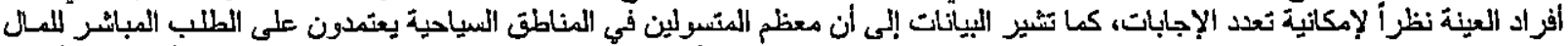

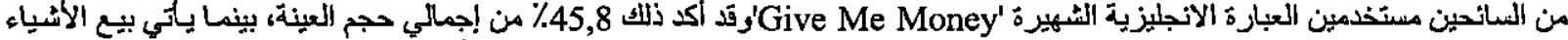

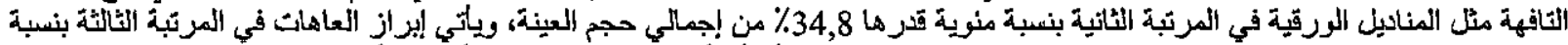

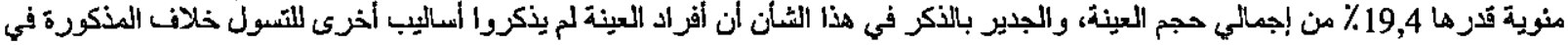
استمارة الاستقصاء.

السوال الرابع

ما هو رد فعل السائحين تجاه هز لاء المتسولين؟
( ) الضيق والتَمر ( )

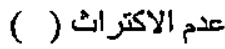

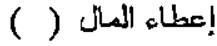

ردود فعل أخرى (يرجى ذكرها)

تشيز البيانات الواردة في الجدول رثم (5) إلى الستجابات أفر اد العينة فيما يخص ردود أفعال السانحين تجاه المتسولين.

جدول 5: ردود أفعال العانحين تجاه العتسولين

\begin{tabular}{|c|c|c|}
\hline النسبة المنوية (\%) & التكر ار (ك) & الاستجابات \\
\hline 8,1 & 10 & إعطاء المال \\
\hline 34,9 & 43 & عنم الاكترات \\
\hline 38,3 & 47 & الضيقي والتذّمر \\
\hline 18,7 & 23 & ردود فعل أخرى \\
\hline 100 & 123 & الإجمالى \\
\hline
\end{tabular}

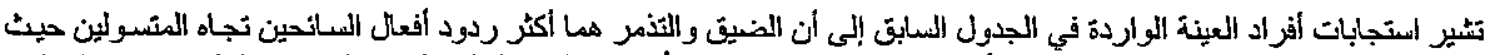

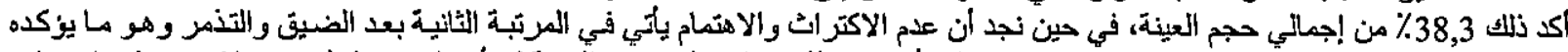

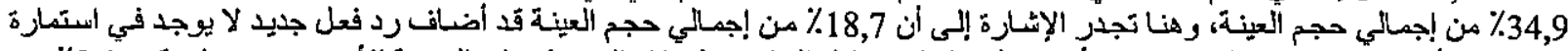

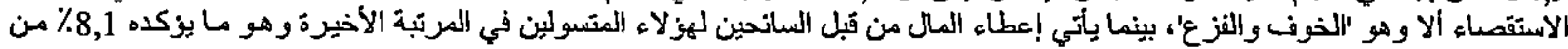


هل ترى ان هناك شعور بالأمان لاى الساتحين في ظلل انتثار ظاهرة التسول بالمناطق السياحية؟

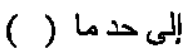
( )

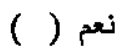

يمكن استعراض استجابات افر اد العينة الخاصة بددى شعور السائحين بالأمان في ظل انتشار ظاهرة التسول على النحو المبين في الجدول رقم

جدول 6: ملى شعور السمانحين بالأمان في ظلا انتشار ظاهرة التسول

\begin{tabular}{|c|c|c|}
\hline النسبة المنوية (\%) & التكر ار (لك) & الاستجابات \\
\hline 9,8 & 12 & نعم \\
\hline 60,9 & 75 & $\bar{y}$ \\
\hline 29,3 & 36 & إلى حذ ما \\
\hline 100 & 123 & الإجمالي \\
\hline
\end{tabular}

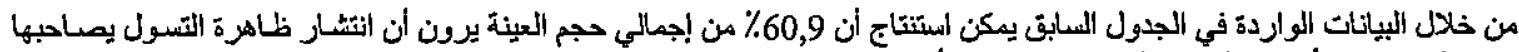

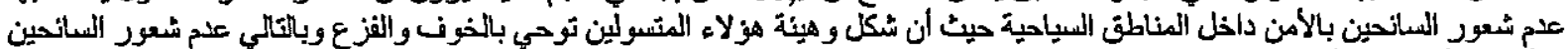

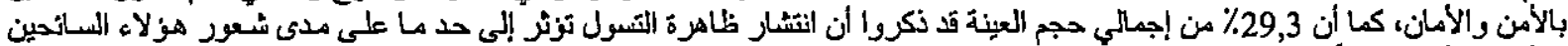

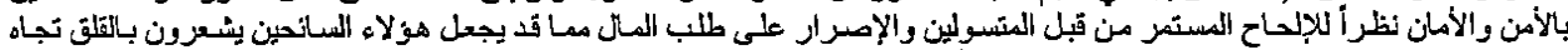

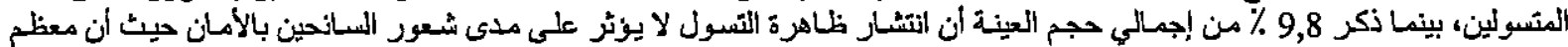

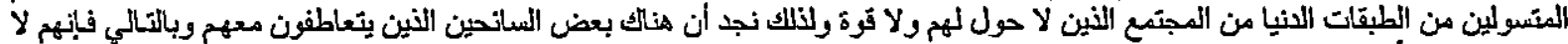

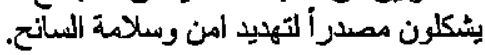

السؤال السادس

هل ترى ان كثرة المتسولين في منطقة عملك تد توتُّر على تربد الساتحين على المنطقة بعد نلك؟

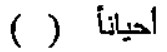
( ) الا

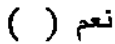

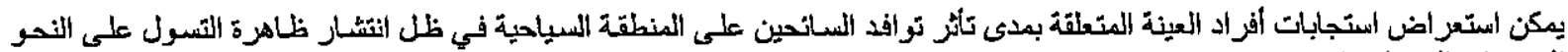
المبين في الجدول رقم (7) (7).

جدول 7: قَلة تواقد السائحين على المناطق السياحية في ظل انتشار ظاهرة التسول

\begin{tabular}{|c|c|c|}
\hline الثنبة المئوينة (\%) & النكر ار (ك) & الآستجابات \\
\hline 53,7 & 66 & نعم \\
\hline 10,6 & 13 & $\bar{y}$ \\
\hline 35,7 & 44 & إلى حد ها \\
\hline 100 & 123 & الإجمالي \\
\hline
\end{tabular}

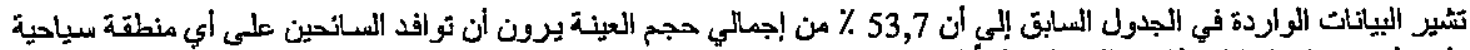

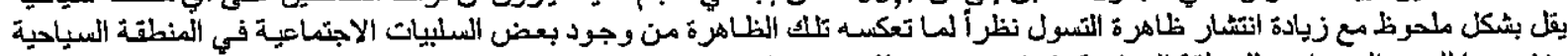

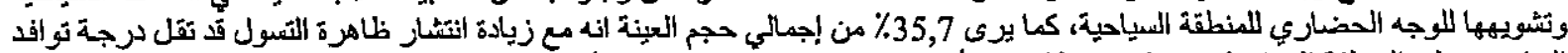

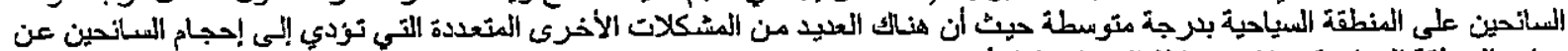

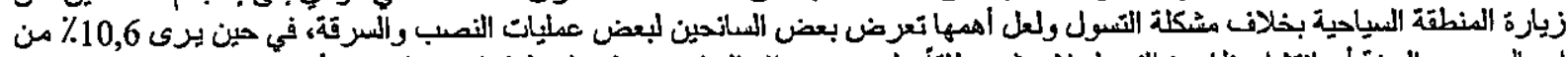

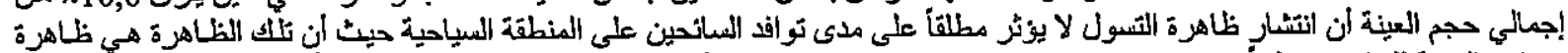

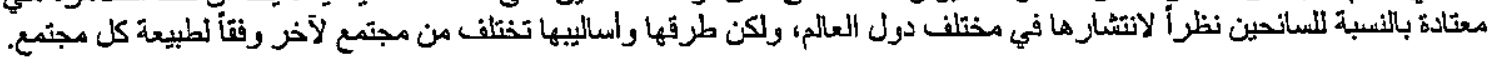

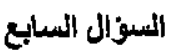

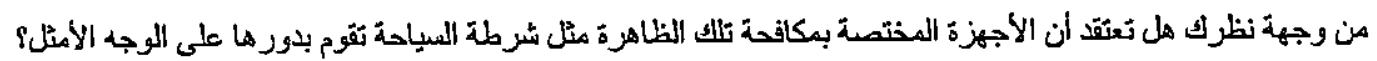
إلى حد ما ( )

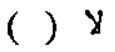

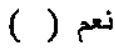

يوضيح الجذول رقم (8) استجابات أفراد العينة فيما يتعلق بمدى قيام الأجهزة المختصة مثل شرطة السياحة بالدور المنوط بها في مواجهة ظاهرة التسول. 
جدول 8: دلى قيام شرطة السياحة بدورها في مواجهة ظاهرة التسول

\begin{tabular}{|c|c|c|}
\hline النسبةٌ المئوية (\%) & آلتكرار (ك) & الاستجابات \\
\hline 20,3 & 25 & نعم \\
\hline 56,9 & 70 & $y$ \\
\hline 22,8 & 28 & إلى حد ما \\
\hline 100 & 123 & الإجمالئ \\
\hline
\end{tabular}

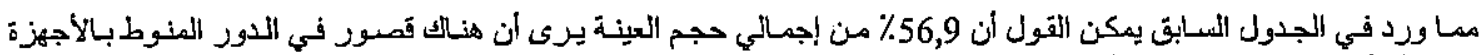

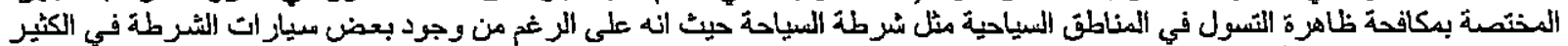

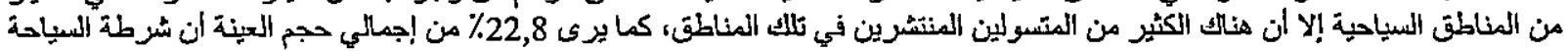

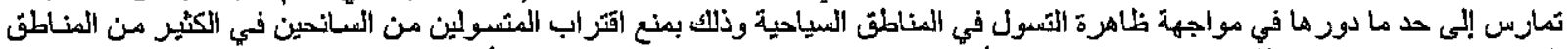

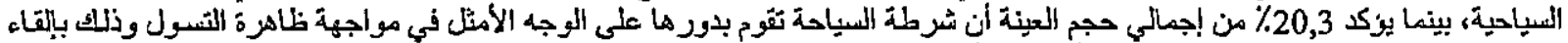

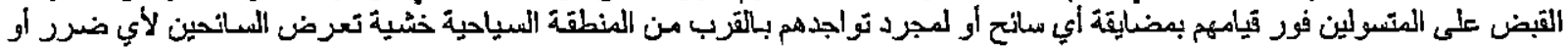

السؤال الثامن

هل ترى أن هنالك وعي من قبل أفراد المجتمع بخطورة تلك المظاهرة وتصديهم للمتسولين عند مضايتهه للسانحين؟
إلى حد ما ( )
( )
( ) نعم ( )

تشير البيانات الواردة في الجدول رقم (9) إلى استجابات أفراد العينة حول مدى وعي أفراد المجتمع بخطورة ظاهرة التسول.

جدول 9: وعي أفراد العجتع بدى خطوة ظاهرة التسول

\begin{tabular}{|c|c|c|}
\hline النسبة المنوية (\%) & التكر ار (ك) & الاستجابات \\
\hline 23,6 & 29 & نعح \\
\hline 59,3 & 73 & $\bar{y}$ \\
\hline 17,1 & 21 & إلى حد ها \\
\hline 100 & 123 & الإجمالمي \\
\hline
\end{tabular}

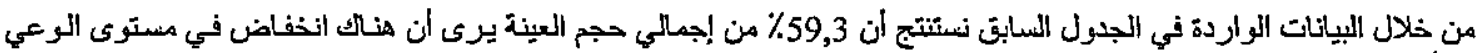

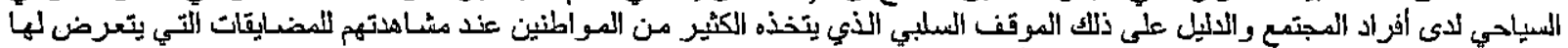

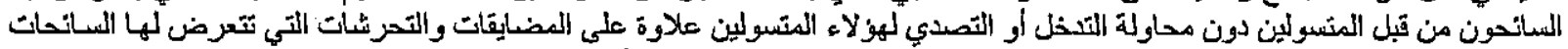

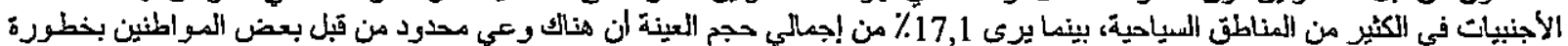

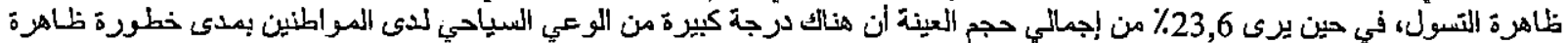

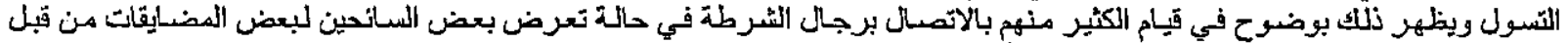

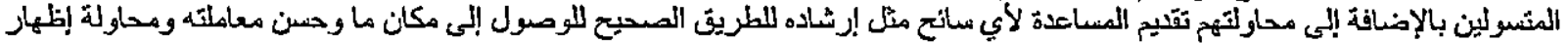
الترحاب و الود له بصفة مستمرة. السؤال التاسيع

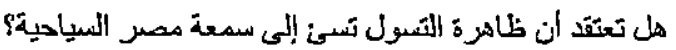

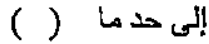
( ) 1
نحم ( ) ندان

تشير البيانات الواردة في الجنول رقم (10) إلى استجابات افراد العينة فيما ينعلق بمدى ارتباطظاهرة التسول بالإساءة لسمعة مصر السياحية. جدول 10: وجود ارتباط بين انتثار ظاهرة التسول والإساوة لسعة مصر السياحية

\begin{tabular}{|c|c|c|}
\hline اللنسبة المنوية (\%) & التكرار (ك) & الاستجبابات \\
\hline 80,5 & 99 & نعم \\
\hline - & 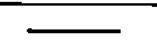 & $\bar{y}$ \\
\hline 19,5 & 24 & إلّى حد ما \\
\hline 100 & 123 & الإجمالى \\
\hline
\end{tabular}


من خلال ما ورد في الجدول السابق من بيانات بتضيح ان هنالك شبه إجماع من جانب معظم أفراد العينة 80,5\% على أن التسول

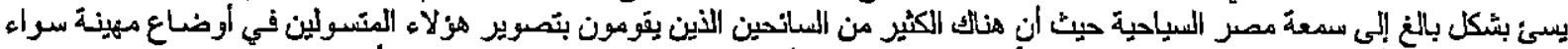

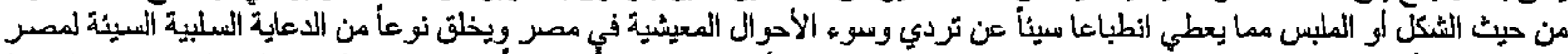

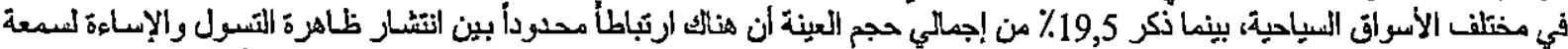

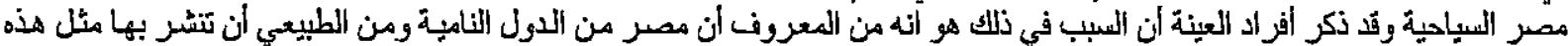

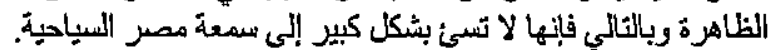

السؤال العاثمر

من وجهة نظرك، ما هي أهم المقترحات التي يمكن من خلالها مكافحة ظاهرة اللتسول؟ يرضح الجدول رقم (11) المقترحات التي أدلى بها أفراد العينة من وجهة نظرهم حول كيفية التصدي لظاهرة التسول بصفة عامة وفي المناطق السياحية بصفة خاصة.

\section{جدول 11: سبل التظب على ظاهرة التسبل}

\begin{tabular}{|c|c|c|}
\hline النسبة المنرية (\%) & التكرار (5) & الاستجابات \\
\hline 21,5 & 47 & التو عية الإعلامية \\
\hline 30,1 & 66 & تفعيل دور شرطة السياحة \\
\hline 11,9 & 26 & وضع قوانين ز اجرة للحد من تلاك الظاهرة \\
\hline 13,7 & 30 & قَبام وزارة الشُنون الاجتماعية بوضع خطة شَاملة لر عابية المنسولين \\
\hline 22,8 & 50 & 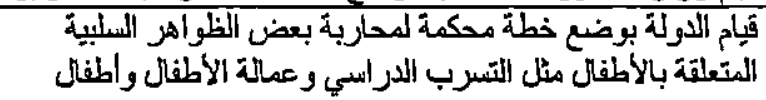 \\
\hline & & الثنو الرع \\
\hline 100 & 219 & 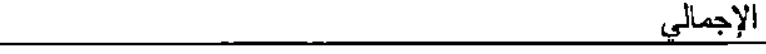 \\
\hline
\end{tabular}

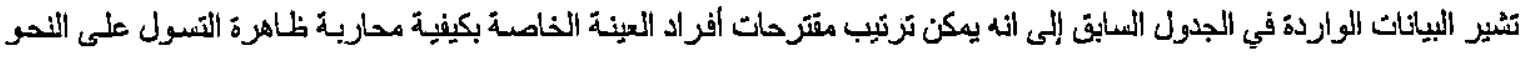

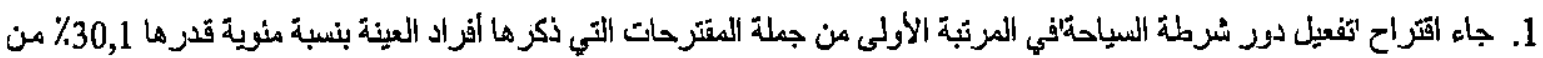

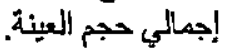

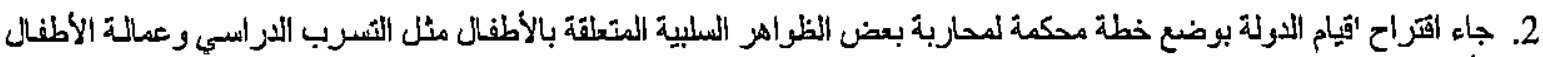

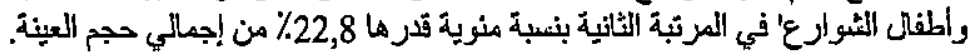

3. جاء اقتراح 'التوعية الإعلامية" في المرتبة الثالثة بنسبة منوية قدرها 21,5٪ من إجمالي حجم العينة.

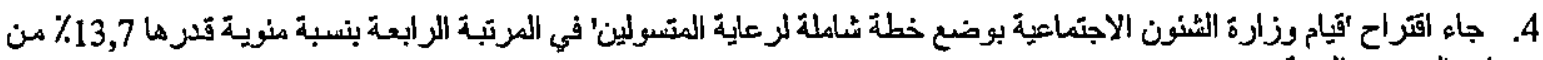
إجمالهي حجم العينة. 5. جاء اقتراح 'وضع قوانين زاجرة اللحد من تلك الطاهرة' في المرتبة الخامسة والاخيرة بنسبة هنوية قهر ها 11,9\% من إجمالي حجم العينة. ويلاحظ أن عدد استجابات أفراد العينة قد زاد عن إجمالمي حجم العينة نظرأ لقيام بعض أفر اد العينة بنكر أكثر من معترح. رابعاً: قياس معاملات الارتباط بين مختلف الأبعاد الواردة في الاراسة الميدانية

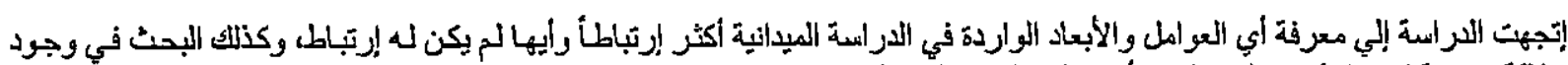

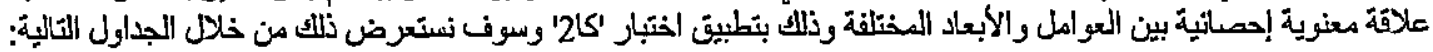
1. الجدول التالي يوضح مدى تواجد المتسولين قرب المناطق السياحية وأكثر الفنات التي تمارس مهنة التسول في المناطق السياحية 
جدول 12

\begin{tabular}{|c|c|c|c|c|c|c|c|}
\hline \multirow{2}{*}{\begin{tabular}{|r|} 
الدلالة \\
الإحصانية \\
sig \\
\end{tabular}} & \multirow{2}{*}{ قيمة كا2 } & \multirow[b]{2}{*}{ الإجمالىى } & \multicolumn{2}{|c|}{ |مدي تواجد المنسّولين قُرب } & \multirow[t]{2}{*}{ |العدد } & \multirow[t]{2}{*}{ |الخيارات } & \\
\hline & & & احياناً & نعم & & & العبارة \\
\hline \multirow[t]{10}{*}{0.000} & \multirow[t]{10}{*}{$67.767^{\mathrm{a}}$} & 51 & 0 & 51 & |العدد & \multirow[t]{2}{*}{ |الاطفال } & \multirow{8}{*}{ 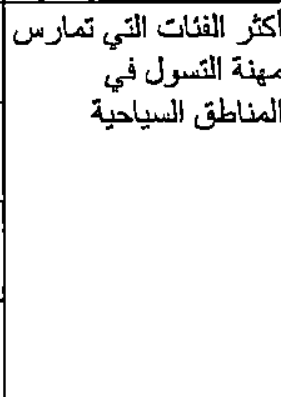 } \\
\hline & & $41.5 \%$ & $.0 \%$ & $41.5 \%$ & |النسبة المنوية & & \\
\hline & & 14 & 0 & 14 & |العدد & \multirow[t]{2}{*}{ |المباب } & \\
\hline & & $11.4 \%$ & $.0 \%$ & $11.4 \%$ & المنببة المتوية & & \\
\hline & & 45 & 22 & 23 & |العدد & \multirow[t]{2}{*}{ |السيدِات } & \\
\hline & & $36.6 \%$ & $17.9 \%$ & $18.7 \%$ & |النسبة المنوية & & \\
\hline & & 13 & 13 & 0 & |العدد & \multirow[t]{2}{*}{ |المسنين } & \\
\hline & & $10.6 \%$ & $10.6 \%$ & $.0 \%$ & الننسبة المنوبة & & \\
\hline & & 123 & 35 & 88 & |العدد & \multirow{2}{*}{\multicolumn{2}{|c|}{ لإجمالى }} \\
\hline & & $100.0 \%$ & $28.5 \%$ & $71.5 \%$ & النسبة المنوبية & & \\
\hline
\end{tabular}

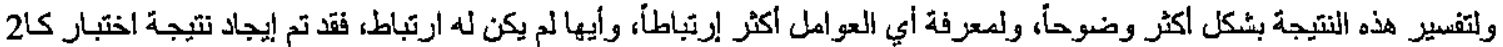

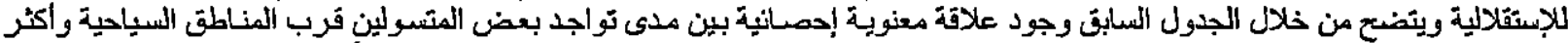

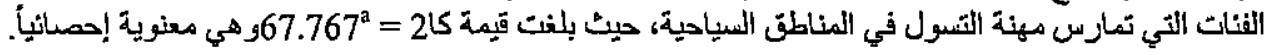

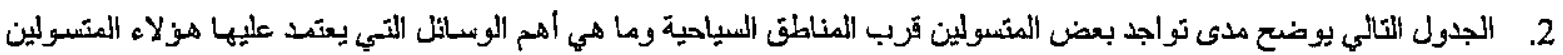

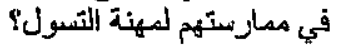

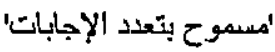

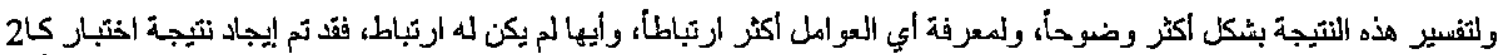

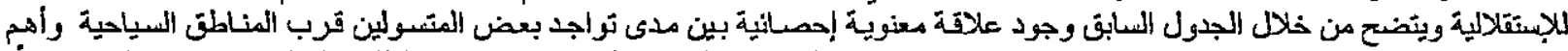

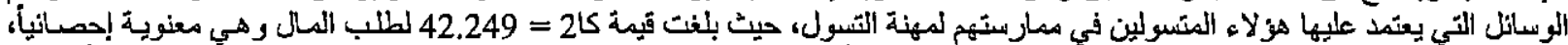

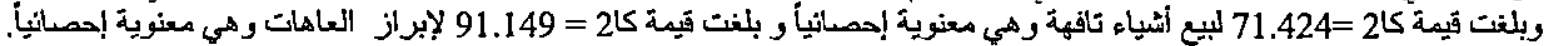

\section{جلول 13}

\begin{tabular}{|c|c|c|c|c|c|c|c|}
\hline \multirow{2}{*}{$\begin{array}{c}\text { الإلالنة } \\
\text { الإحصانية } \\
\text { sig }\end{array}$} & \multirow{2}{*}{ قيمة كا2 } & \multirow[b]{2}{*}{ الإجمالىى } & \multicolumn{2}{|c|}{ مدى تواجد المتسولين قرب المناطق } & \multirow[t]{2}{*}{ العدد } & \multirow[t]{2}{*}{ الخيارات } & \multirow[t]{2}{*}{ العبارة } \\
\hline & & & الحباناً & نعم & & & \\
\hline \multirow[t]{2}{*}{0.000} & 42.249 & 66 & 35 & 31 & المدد & \multirow[t]{2}{*}{ طلب المال } & \multirow{6}{*}{ 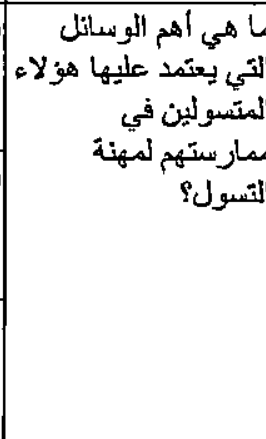 } \\
\hline & & $45.8 \%$ & $24.3 \%$ & $21.5 \%$ & المنوية النية & & \\
\hline \multirow[t]{2}{*}{0.000} & 71.424 & 50 & 35 & 15 & العدد & \multirow[t]{2}{*}{ بييع أثياء تافهة } & \\
\hline & & $34.7 \%$ & $24.3 \%$ & $10.4 \%$ & المنية النية & & \\
\hline \multirow[t]{4}{*}{0.000} & 91.149 & 28 & 28 & 0 & العدد & \multirow[t]{2}{*}{ ايراز العاهات } & \\
\hline & & $19.4 \%$ & $19.4 \%$ & $.0 \%$ & المنوبة النية & & \\
\hline & & 144 & 98 & 46 & العدد & \multirow{2}{*}{\multicolumn{2}{|c|}{ الإجمائى }} \\
\hline & & $100.0 \%$ & $68.1 \%$ & $31.9 \%$ & المنية النية & & \\
\hline
\end{tabular}

3. الجدول التّالمي يوضنح مدى تواجد المتسولين قرب المناطق السياحية وما هو رد فحل الساتحين تجاه هوَلاء المتسولين. 


\section{جدول 14}

\begin{tabular}{|c|c|c|c|c|c|c|c|}
\hline \multirow{2}{*}{ |الإحصائية الالالة } & \multirow[t]{2}{*}{ قيمة كا2 } & \multirow[b]{2}{*}{ الإجمالى } & \multicolumn{2}{|c|}{ مدى تواجد المتسولين قرب المناطق } & \multirow[t]{2}{*}{ العدد } & \multirow[t]{2}{*}{ الخيارات } & \multirow[t]{2}{*}{ العبارة } \\
\hline & & & أحياناً & نعم & & & \\
\hline \multirow[t]{10}{*}{0.000} & \multirow[t]{9}{*}{79.105} & 10 & 0 & 10 & |لالعدد & \multirow[t]{2}{*}{ إعطاء المال } & \multirow{10}{*}{ ردود أفعال العانحين تجاه } \\
\hline & & $8.1 \%$ & $.0 \%$ & $8.1 \%$ & النسبة المنوية & & \\
\hline & & 43 & 0 & 43 & العدد & \multirow[t]{2}{*}{ عدم الإكترات } & \\
\hline & & $35.0 \%$ & $.0 \%$ & $35.0 \%$ & المسبة المئوية & & \\
\hline & & 47 & 12 & 35 & العدد & \multirow[t]{2}{*}{ الضيق والتنّم } & \\
\hline & & $38.2 \%$ & $9.8 \%$ & $28.5 \%$ & النسبة المنوية & & \\
\hline & & 23 & 23 & 0 & العدد & \multirow[t]{2}{*}{ ردود فعل أخرى } & \\
\hline & & $18.7 \%$ & $18.7 \%$ & $.0 \%$ & النسبة المنوية & & \\
\hline & & 123 & 35 & 88 & العدد & \multirow[t]{2}{*}{ الإجمالىى| } & \\
\hline & & $100.0 \%$ & $28.5 \%$ & $71.5 \%$ & التسبة المنوية & & \\
\hline
\end{tabular}

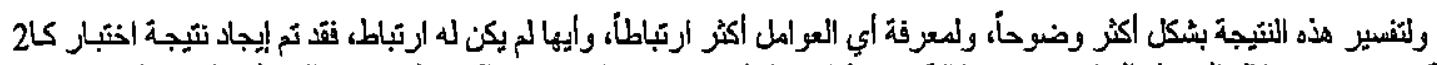

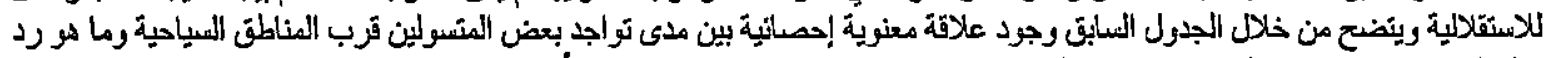

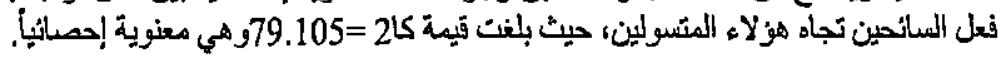

4. الجدول التالكي يوضح مدى تواجد المتسولين قرب المناطق السياحية ومدى شعور الساتحين بالأمان في ظل إنتشار ظاهرة التسول.

\section{جلول 15}

\begin{tabular}{|c|c|c|c|c|c|c|c|}
\hline \multirow{2}{*}{ |الإحصائية الدالة } & \multirow[t]{2}{*}{ قيمة كا2 } & \multirow[b]{2}{*}{ الإجمالثى } & \multicolumn{2}{|c|}{ مدى تواجد المتسّولينَ قرب المناطق } & \multirow[t]{2}{*}{ العدد } & \multirow[t]{2}{*}{ الخيارات } & \multirow[t]{2}{*}{ العبارة } \\
\hline & & & الحياناً & نعم & & & \\
\hline \multirow[t]{8}{*}{0.000} & \multirow[t]{8}{*}{118.224} & 12 & 0 & 12 & العدد & \multirow[t]{2}{*}{ نعم } & \multirow{6}{*}{ ظل انتشار ظاهرة الساتحِين بالأمان في } \\
\hline & & $9.8 \%$ & $.0 \%$ & $9.8 \%$ & اللنسبة المنوية & & \\
\hline & & 75 & 0 & 75 & العدد & \multirow[t]{2}{*}{$y$} & \\
\hline & & $61.0 \%$ & $.0 \%$ & $61.0 \%$ & إلنسبة المنوية & & \\
\hline & & 36 & 35 & 1 & العدد & \multirow[t]{2}{*}{ أحياناً } & \\
\hline & & $29.3 \%$ & $28.5 \%$ & $.8 \%$ & التسبية المنوية & & \\
\hline & & 123 & 35 & 88 & العدد & \multirow[t]{2}{*}{ الإجمالى } & \\
\hline & & $100.0 \%$ & $28.5 \%$ & $71.5 \%$ & النسبة المتوية & & \\
\hline
\end{tabular}

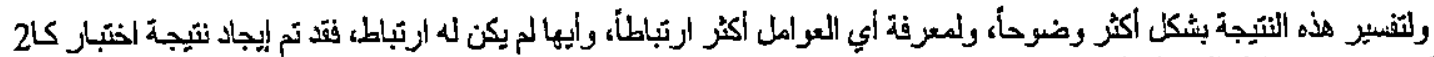

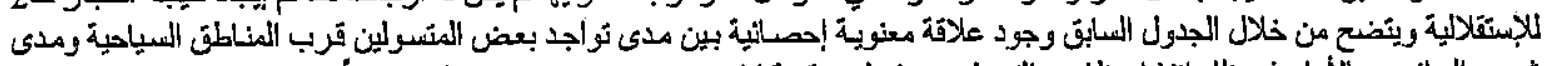

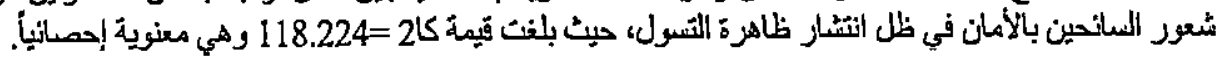

5. الجنول التالي يوضح مدى تواجد المتسولين قرب المناطق السياحية وقلة تواقد السائحين على المناطق السياحية في ظلل إنشار ظاهزة التسول. 
جدول

\begin{tabular}{|c|c|c|c|c|c|c|c|}
\hline \multirow{2}{*}{ الإحصانية الدالة } & \multirow[t]{2}{*}{ قيمة كا2 } & \multirow[b]{2}{*}{ الإجمالى } & \multicolumn{2}{|c|}{ مدى تو اجد المتسولينة قرب المناطق } & \multirow[t]{2}{*}{ العدد } & \multirow[t]{2}{*}{ الخيارات } & \multirow[t]{2}{*}{ العبارة } \\
\hline & & & أحياناً & نعم & & & \\
\hline \multirow[t]{8}{*}{0.000} & \multirow[t]{8}{*}{87.834} & 66 & 0 & 66 & العند & \multirow[t]{2}{*}{ نعק| } & \multirow{6}{*}{ 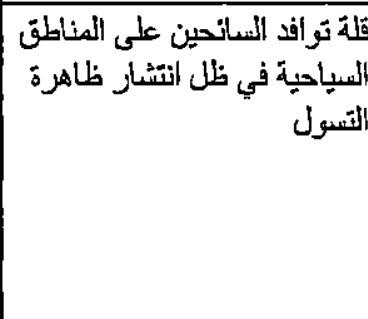 } \\
\hline & & $53.7 \%$ & $.0 \%$ & $53.7 \%$ & النسبة المئوية & & \\
\hline & & 13 & 0 & 13 & العدد & \multirow[t]{2}{*}{$y$} & \\
\hline & & $10.6 \%$ & $.0 \%$ & $10.6 \%$ & النتبية المئوية & & \\
\hline & & 44 & 35 & 9 & العدد & \multirow[t]{2}{*}{ أحياناً } & \\
\hline & & $35.8 \%$ & $28.5 \%$ & $7.3 \%$ & النسبة المئوية & & \\
\hline & & 123 & 35 & 88 & العدد & \multirow[t]{2}{*}{ الإجمالى } & \\
\hline & & $100.0 \%$ & $28.5 \%$ & $71.5 \%$ & النسبة المنرية & & \\
\hline
\end{tabular}

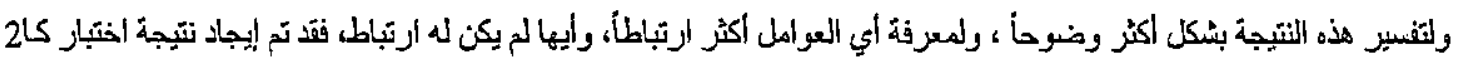

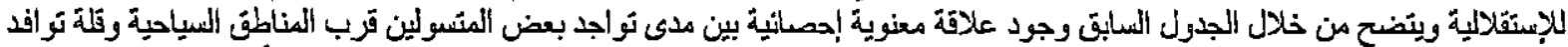

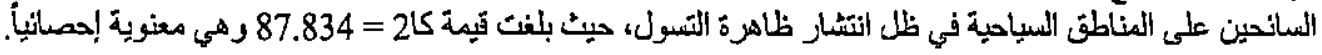

6. الجدول التالي يوضح مدى تواجد المتسولين قرب المناطق السياحية رمدى قيام شرطة النساحة بدور ها في مواجهة ظاهزة التسول.

جـ

\begin{tabular}{|c|c|c|c|c|c|c|c|}
\hline \multirow{2}{*}{ الإحصانية الالالة } & \multirow[t]{2}{*}{ قيمة كا2 } & \multirow[b]{2}{*}{ الإجمالى } & \multicolumn{2}{|c|}{ |مدى تواجذ المتسولين قرب المناطق } & \multirow[t]{2}{*}{ العدد } & \multirow[t]{2}{*}{ الخيارات } & \multirow[t]{2}{*}{ العبارة } \\
\hline & & & أحياناً & نعم & & & \\
\hline \multirow[t]{8}{*}{0.000} & \multirow[t]{7}{*}{92.054} & 25 & 0 & 25 & العدد & \multirow[t]{2}{*}{ نعح } & \multirow{6}{*}{ 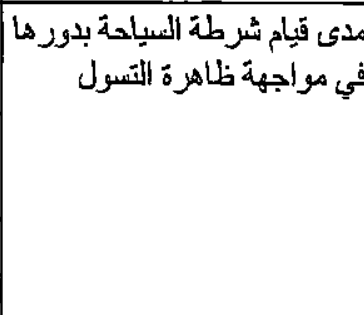 } \\
\hline & & $20.3 \%$ & $.0 \%$ & $20.3 \%$ & النسبة المنورية & & \\
\hline & & 70 & 7 & 63 & العدد & \multirow[t]{2}{*}{$y$} & \\
\hline & & $56.9 \%$ & $5.7 \%$ & $51.2 \%$ & إلنسبة المئوية & & \\
\hline & & 28 & 28 & 0 & العدد & \multirow[t]{2}{*}{ أحياناً } & \\
\hline & & $22.8 \%$ & $22.8 \%$ & $.0 \%$ & النسبة المنوية & & \\
\hline & & 123 & 35 & 88 & العند & \multirow[t]{2}{*}{ الإجمالى } & \\
\hline & & $100.0 \%$ & $28.5 \%$ & $71.5 \%$ & النسبة المنورية & & \\
\hline
\end{tabular}

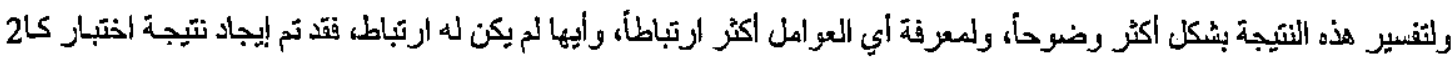

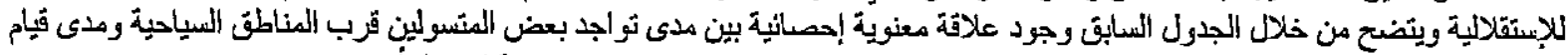

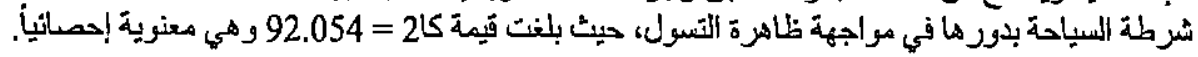
7. الجبرل التأي يوضح مدى تواجد المتسولين قربب المناطق السياحية ووعي أفراد المجتمع بدى خطورة ظاهرة التسول 


\section{جدول 18}

\begin{tabular}{|c|c|c|c|c|c|c|c|}
\hline \multirow{2}{*}{ 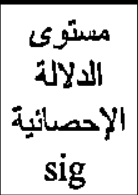 } & \multirow{2}{*}{ قيمة كا2 } & \multirow[b]{2}{*}{ الإجمالى } & \multicolumn{2}{|c|}{ مدى تواجد المتسولين قرب المناطق } & \multirow[t]{2}{*}{ العدد } & \multirow[t]{2}{*}{ الخيارات } & \multirow[t]{2}{*}{ العبارة } \\
\hline & & & أحيانا & نعم & & & \\
\hline \multirow[t]{8}{*}{0.000} & 67.420 & 29 & 0 & 29 & العدد & \multirow[t]{2}{*}{ نعקر } & \multirow{6}{*}{ 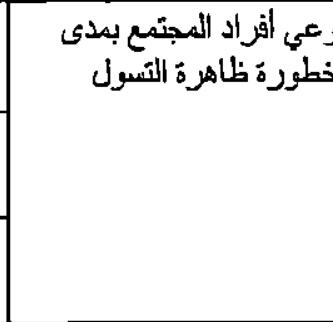 } \\
\hline & & $23.6 \%$ & $.0 \%$ & $23.6 \%$ & النعبة المنوية] & & \\
\hline & & 73 & 14 & 59 & العدد & \multirow[t]{2}{*}{$y$} & \\
\hline & & $59.3 \%$ & $11.4 \%$ & $48.0 \%$ & النسبة المئوية & & \\
\hline & & 21 & 21 & 0 & العدد & \multirow[t]{2}{*}{ احيانأ } & \\
\hline & & $17.1 \%$ & $17.1 \%$ & $.0 \%$ & النسبة المنوية & & \\
\hline & & 123 & 35 & 88 & العدد & \multirow[t]{2}{*}{ الإجمالى } & \\
\hline & & $100.0 \%$ & $28.5 \%$ & $71.5 \%$ & التنسبة المنوبية & & \\
\hline
\end{tabular}

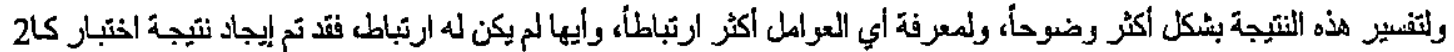

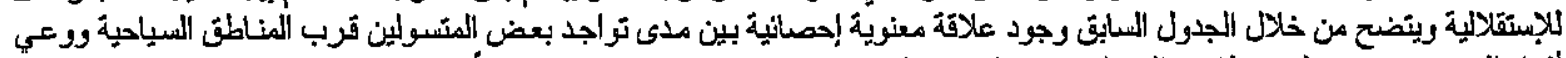

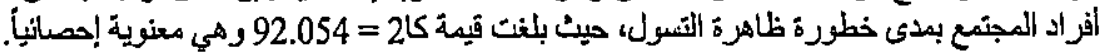

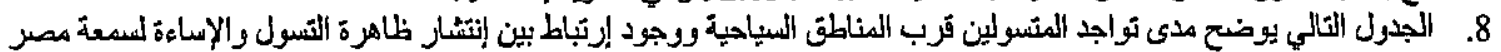

\section{جدول 19}

السياحية.

\begin{tabular}{|c|c|c|c|c|c|c|c|}
\hline \multirow{2}{*}{$\begin{array}{c}\text { الإلالةية } \\
\text { الإنصانية } \\
\text { sig }\end{array}$} & \multirow{2}{*}{ قتيمة كا2 } & \multirow[b]{2}{*}{ الاجمالى } & \multicolumn{2}{|c|}{ مدى تواجد المتسولينة قرب المناطق } & \multirow{2}{*}{ العدد } & \multirow{2}{*}{ |الخيارات | } & \multirow[t]{2}{*}{ العبازة } \\
\hline & & & أحيانأ & نعم & & & \\
\hline \multirow[t]{6}{*}{0.000} & 74.971 & 99 & 11 & 88 & العدد & \multirow[t]{2}{*}{ نعح } & \multirow{4}{*}{ 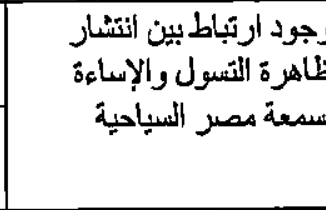 } \\
\hline & & $80.4 \%$ & $8.9 \%$ & $71.5 \%$ & المنبة المنوية & & \\
\hline & & 24 & 24 & 0 & العدد & \multirow[t]{2}{*}{ أحياناً } & \\
\hline & & $19.5 \%$ & $19.5 \%$ & $.0 \%$ & النسبة المنوية & & \\
\hline & & 123 & 35 & 88 & العدد & \multirow[t]{2}{*}{ الإجمالىى } & \\
\hline & & $100.0 \%$ & $28.5 \%$ & $71.5 \%$ & النسبة المنوية & & \\
\hline
\end{tabular}

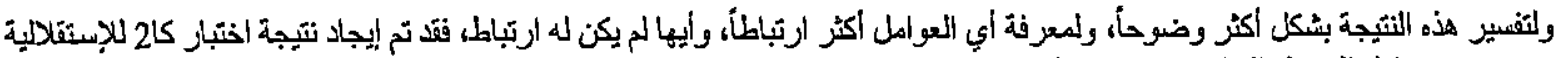

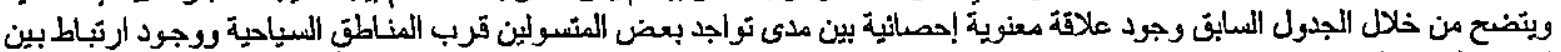

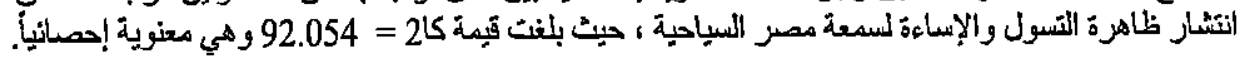

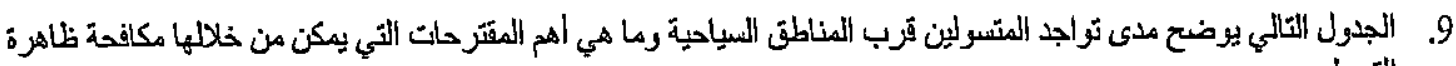
التسول. 
جدول

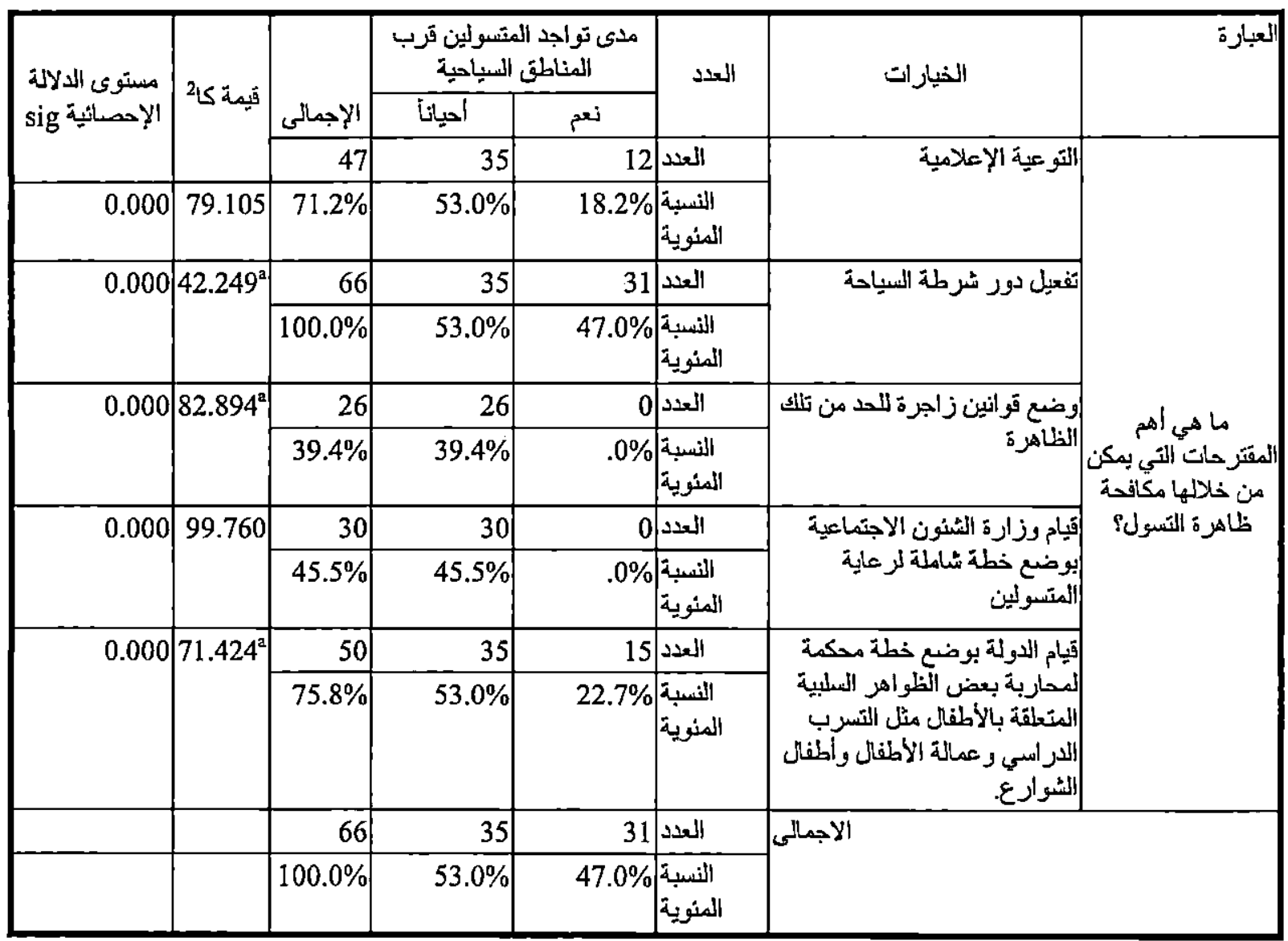

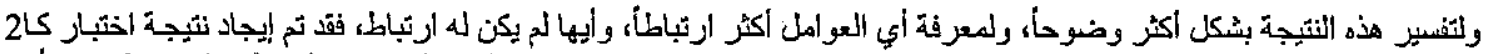

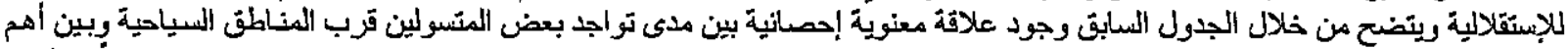

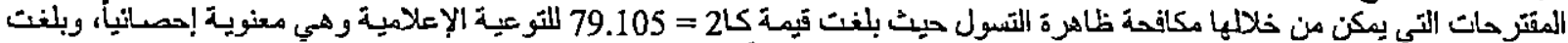

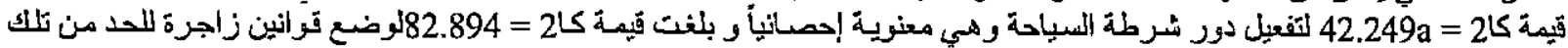

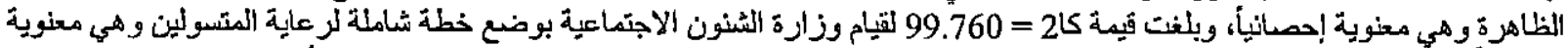

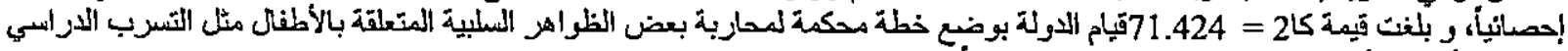

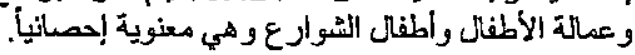

إلتأكد من صحة فرض الاراسة

جاء في فرض الاراعة 'إن انتشار ظاهرة التسول في الكثير من المناطق العياحية في مصر سينعكس بصورة سلبية على مدى تردد السعاتحين على المقصد المياحي المصري على المئي المدى البعيد'.

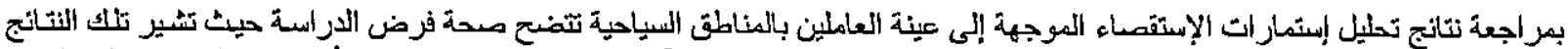

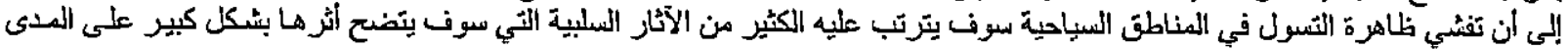

البعيد وذذانك للأسباب الآَيَّة:

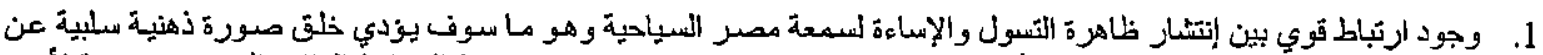

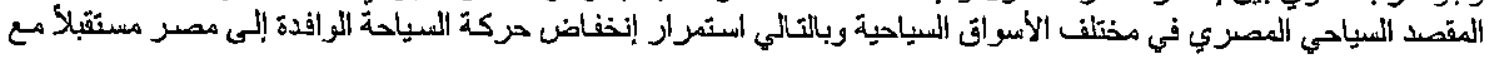
استمرار تنامي تلك الظاهزة.

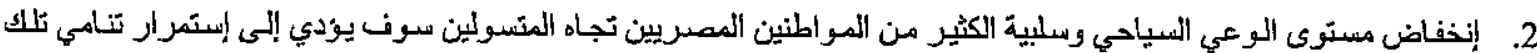

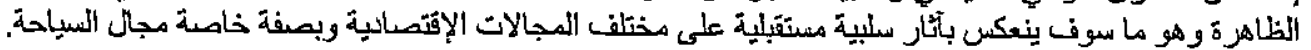

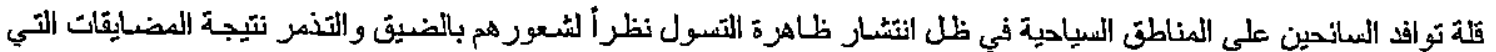

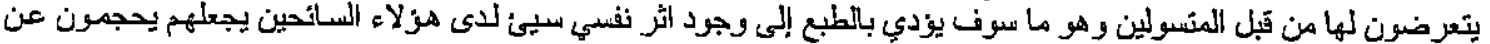
.3 


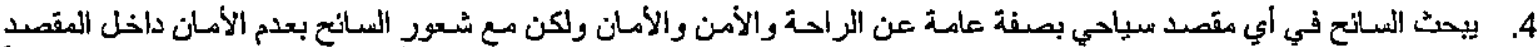

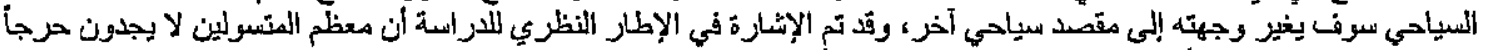

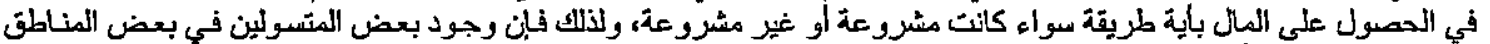

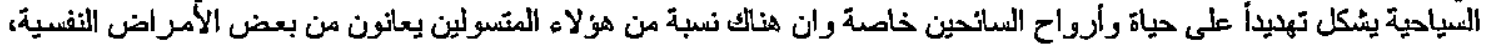

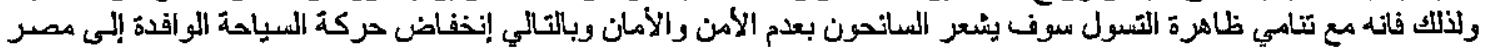
على المدى البحيد.

تمخضت الدراسة من خلال شقيها النظري والميداني عن مجموعة من إلنتانج الهامة التي يمكن توضيحها على النحو التالتي:

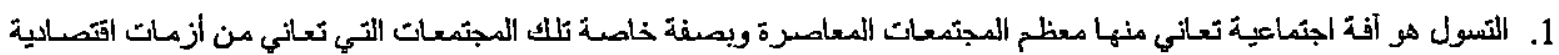
طاحنّميرتفع فيها معدلات الفقتر واليطالة.

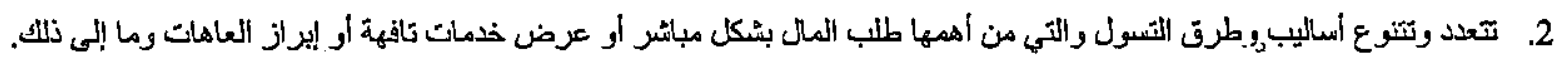

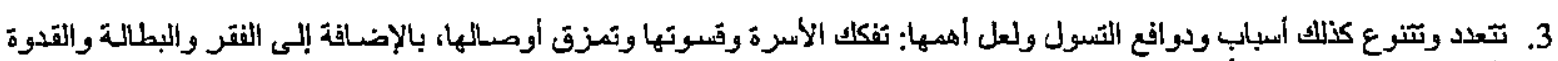

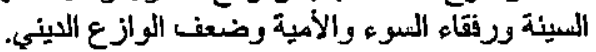

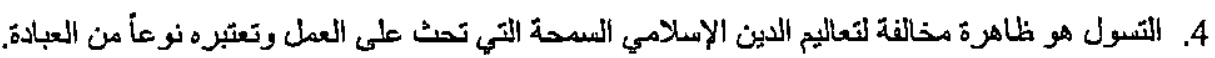

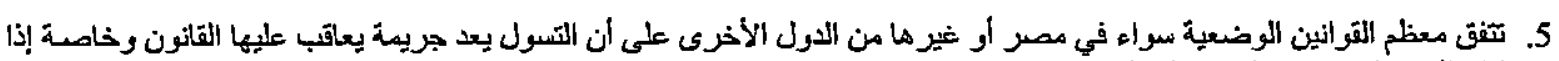

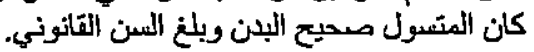

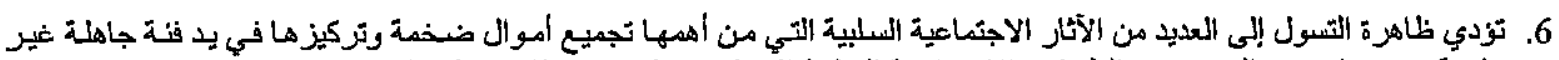

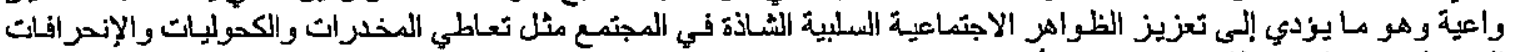
الجنسية وغير ها من مظاهر الإنحران الأخلاقي.

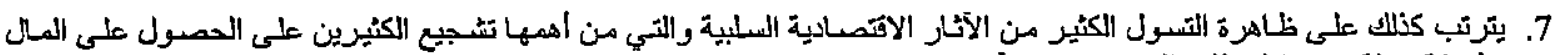

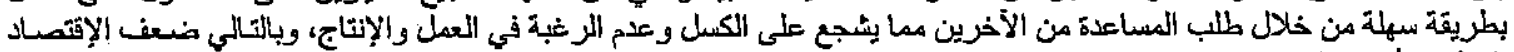
الوطني لأي دولة.

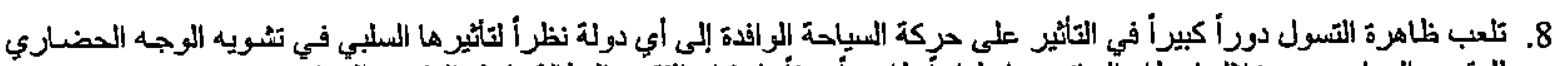

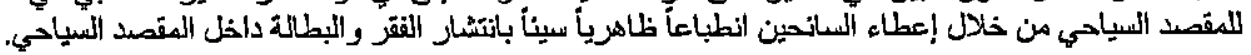

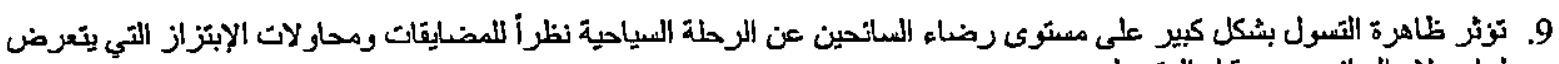
لها هؤلاء الساتحين هن قبل المتسولين.

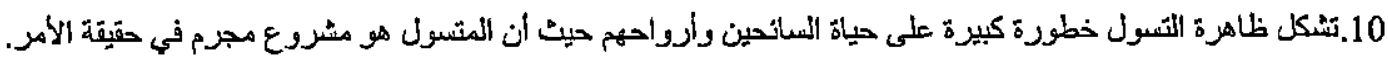

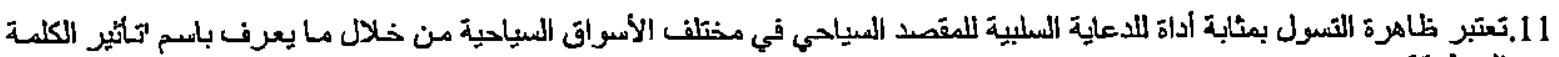
المنظوقة'.

12.يعتبر إنخفاض مستوى الوعي السياحي من أهم الأسباب المؤدية إلى انتشار ظاهرة التسول في الدول السياحية.

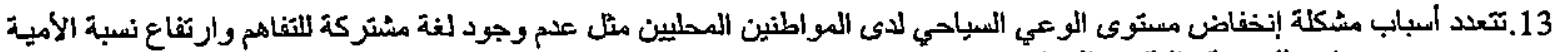

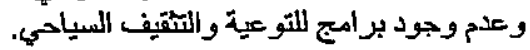

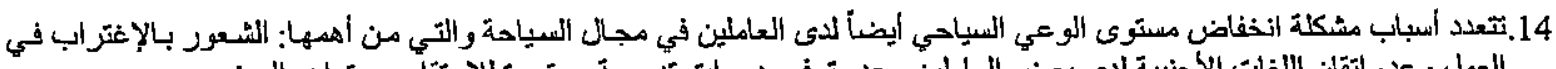

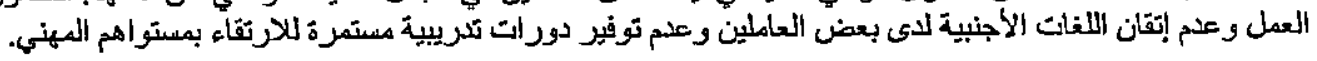

مقترحات وتوصيات الاراسة

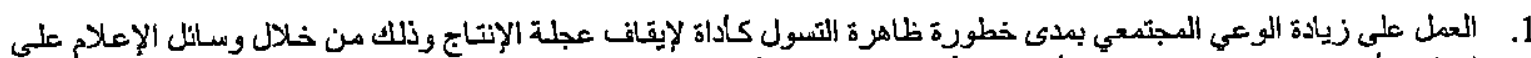

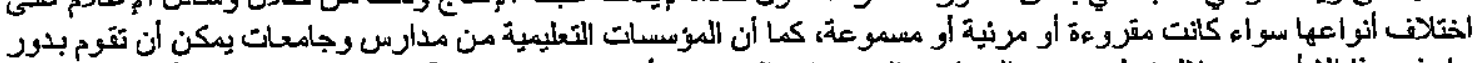

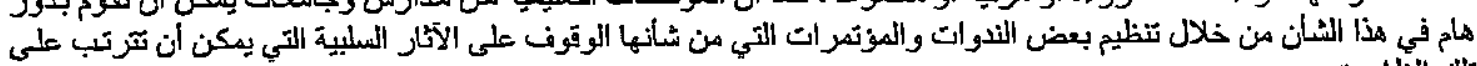

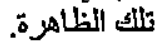

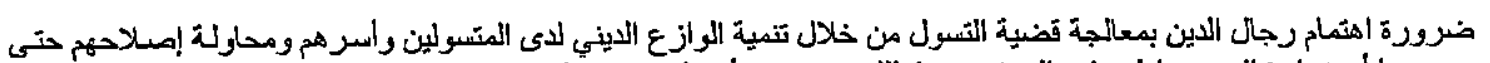

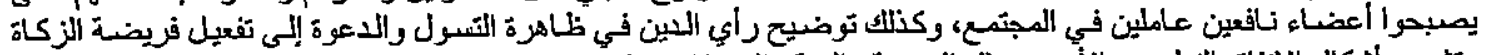

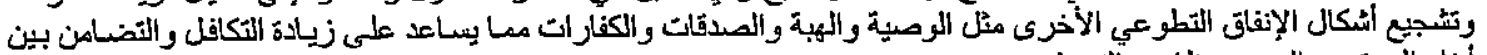

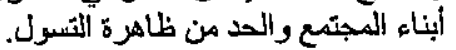

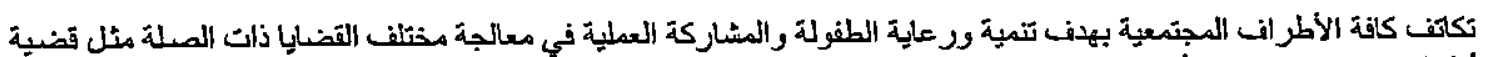

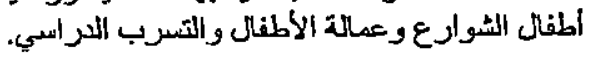


4. إجراء بعض التعديلات على قانون التسول بحيث يجب تشديد عقوبة التسول لتصبح الحبس لمدة عام على الاقل، وفي حالة العود يتّم

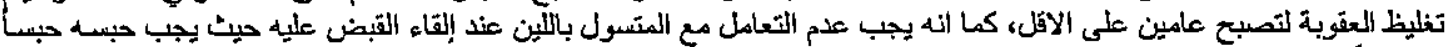

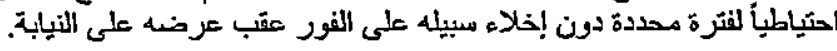

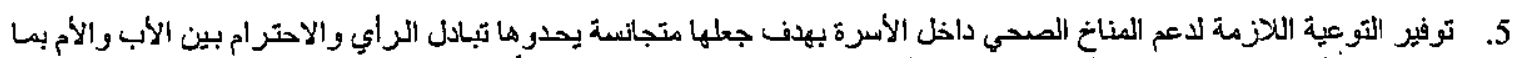

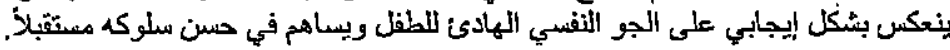

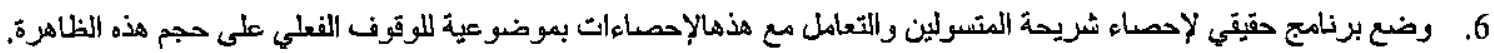

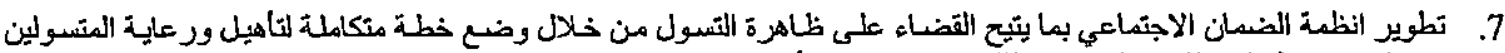

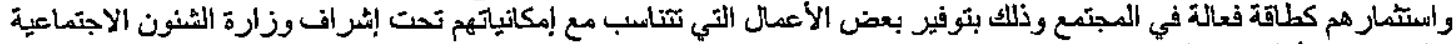
و الجمعيات الأهلية ومنظمات المجتمع المدني.

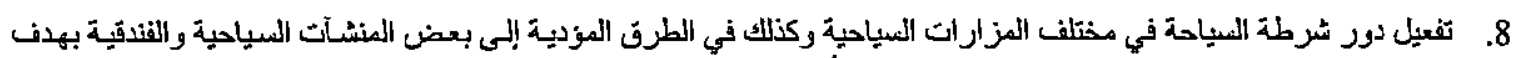

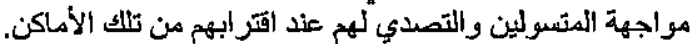
9. بالإضافة إلى دور شر طة السباحة فإنه يجب الاستعانة ببعض الفراد الأمن المدربين لإحكام الرقابة والسيطرة على مختلف المزارات الكياحية بما يمنع وجود مثل هذه الظاهرة.

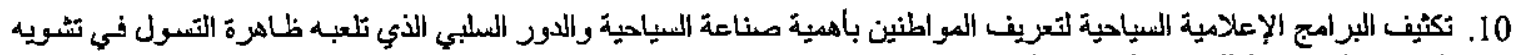

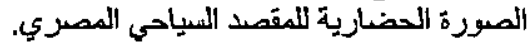

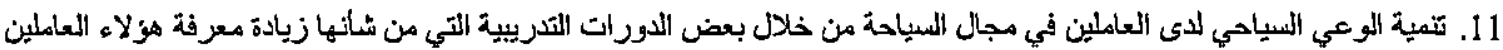

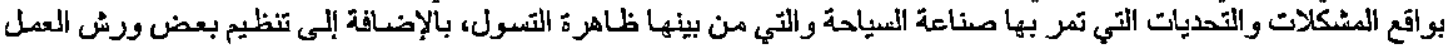

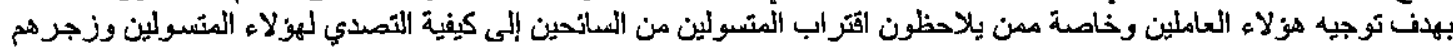

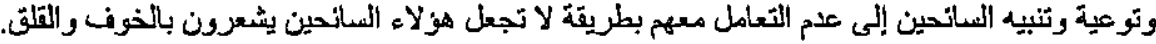

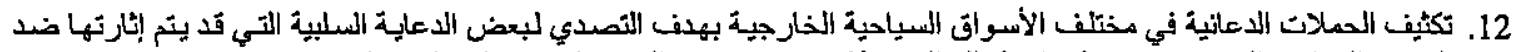

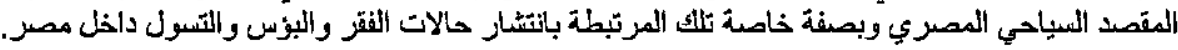

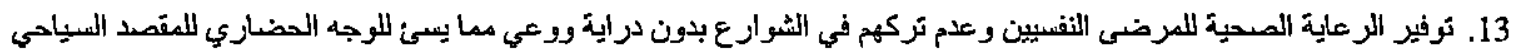
المصري.

14. السعي المستمر من جانب الحكومة نحو القضاء على مشكلة العشو انيات الكونها احد الأسباب المزدية إلى انتشـار ظـاهرة التسول بما تفرزه تلكا العُشواتيات من مئات المتسولين. 15. تشجيع الأبحاث العلمبة الثتي تثناول قضية التسول من مختلف جوانبها الاقتصادية والاجتماعية والجنانية بهدن الوقون على البعاد هذه القضّية ووضع الحلول النفاعلة لها.

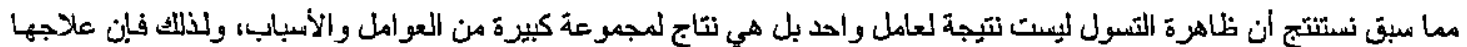

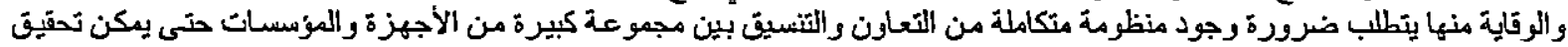

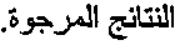

1. فاروق محمد العادلي (2006)، ظاهرة التسول، مركز البحوث والدراسات الاجتماعية، كلية الآداب، جامعة القاهرة، القاهرة، ص 15.

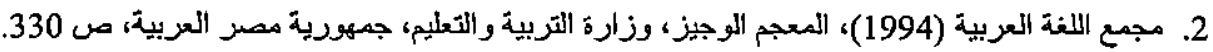

3. Sharma, R. (1998), Social Problems and Welfare, Atlantic Publishers and Distributors, Ballia, p. 90. 4. محمد أبو سريع (1986)، ظاهرة التسول ومعوقات مكافتها، من الأبحاث المقدمة لأكاديمية الشرطة بالقاهرة، ص 4.

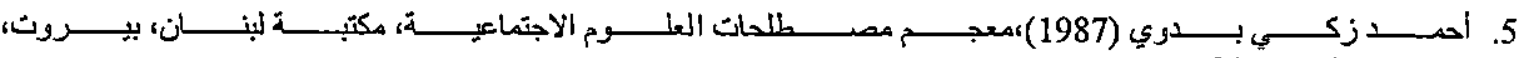
ص ص 438، 37، 81 .

6. Bid, D. (2006), Sociology for Physiotherapists, Jaypee Brothers Publishers, Balangir. P. 48.

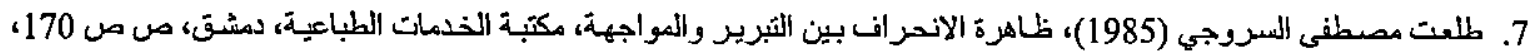

8. Parashar, P. (2003),History and Problems of Municipal Administration in India, Sarup \& Sons, Burla, p. 48 .

9. محمود كسناوي (2002)، ظاهزة النلوكيات الخاطنة أثناء موسم الحج: الواقع والحلول، معهد خادم الحرمين الثريفين، جدة، ص 12.

10.Tolstoy, C. (2010), A Russian Proprietor and Other Stories, Wildside Press, Los Angles, p. 91. 
11.Madan, G. (2003), Sociology of Development, Allied Publishers, Chamba, p. 82.

12.http://www.aleqt.com/2007/11/09/article_10536.html, accessed on 5/1/2012.

13.Mayhew, H. (2009), London Labour and the London Poor, Cosimo, New York, p. 393.

14.المامون الطيب (2010)، مشكلة التُسول في البيينة الحضرية دراسة تطبيقية على المتسولين بمدينة الرياض، المركز الوطني للقياس

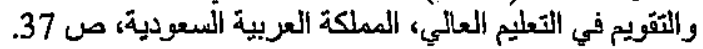

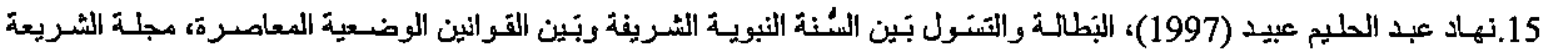

والدر اسات الإسلامية، الكويت، المجلد 12، العدد 31، ص ص صن 99، 105.

16.Goyal, O. (2005), Anti-Social Patterns of Begging and Beggars, Gyan Publishing House, Chandil, p. 167.

17.محمد الأمين البثرى (1999)، أنماط الجرائي في الموطن العربي، جامعة نايف العربية للعلوم الأمنية، الرياض، المملكة العربية السعودية، ص ص الامين البثرى 125.

18.غادة على حمود (2010)،السياحة: الماضي، الحاضر، المستقّل (الجزء الثاني)، مطبعة علاء الدين، القاهرة، ص 140.

19.Martinez, O. (2003), U.S.-Mexico Borderlands: Historical and Contemporary Perspectives, Rowman and Little Field, USA, p. 239.

20.McLaren, D. (2003), Rethinking Tourism \& Eco Travel, Kumarian Press, Los Angles, p. 78.

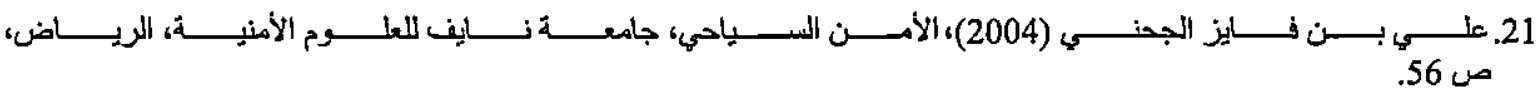

22.Kozak, M. and Baloglu, S. (2011), "Managing and Marketing Tourist Destinations: Strategies to Gain a Competitive Edge", Routledge, New York p. 65.

23.محمود كسناوي (1987)، دراسة مسحية حول ظاهرة التسول من قَبل الحجيج، جامعة أم القرى، مركز أبحاث الحج، الرياض، ص 2. 24.سيير عبد اللطيف ابو العلا (1990)،دور التربية في تنمية الوعي السياحي باسوان، رسالة ماجستير غير منثورة، كلية التربية،

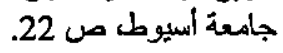

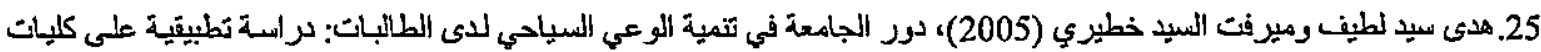

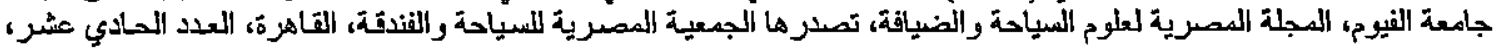

ص 63.

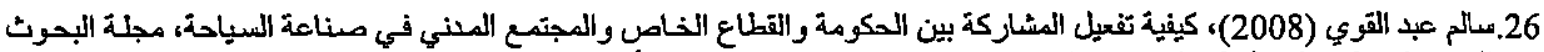

السياحية، قطاع التخطيط و البحوث والتدريب، وزارة السياحة، القاهرة، عدد أكتوبر، ص صل ص 40 - 45

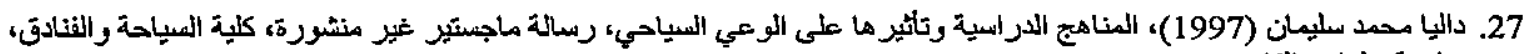

جامعة حلوان، القاهرة، ص 42.

الملاحق

استمازة استقصاء موجهة إلى العاملين في بعض المناطق السياحية بمنطقة القاهرة الكبرى

تحية طيبة وبعد،،

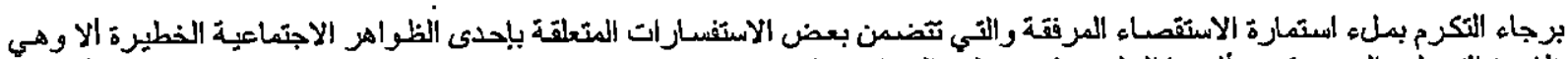

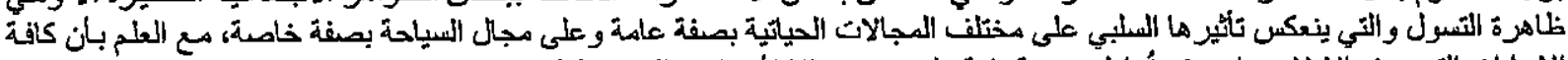

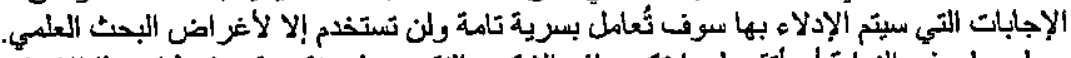

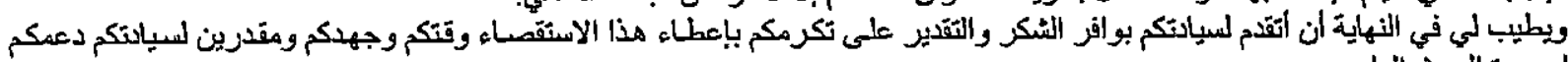
لمسيرة البحث العلمي.

$$
\text { وتفضلوا بقبول فانتى الاحترام والتقنير }
$$




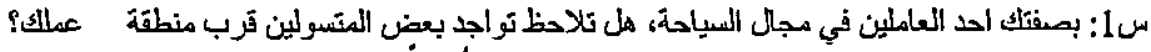

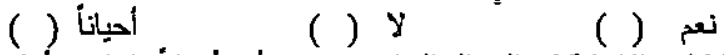

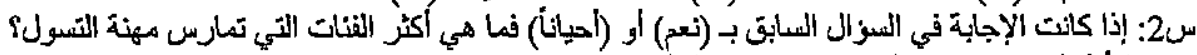

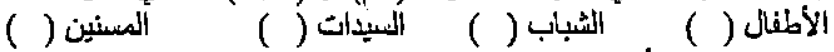

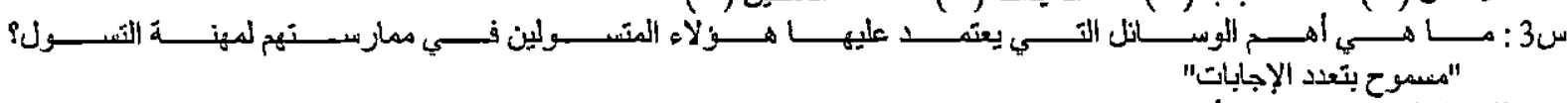

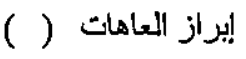

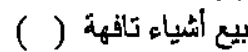

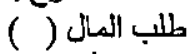

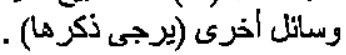

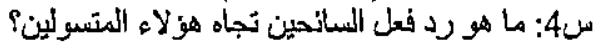

$$
\begin{aligned}
& \text { الضيق والتذمر ( ) }
\end{aligned}
$$

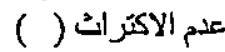

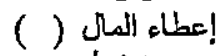

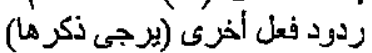

$$
\begin{aligned}
& \text { س5: هل ترى أن هناك شعور بالأمان لاى السانحمِن في ظلل انتشار ظاهزة التسول بالمناطق السياحية؟ }
\end{aligned}
$$

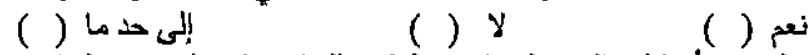

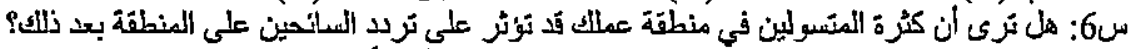

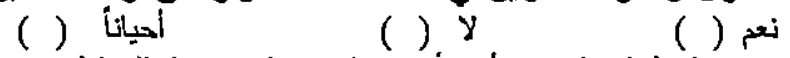

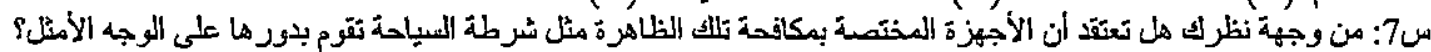

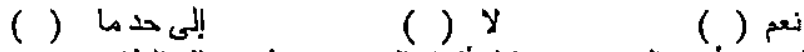

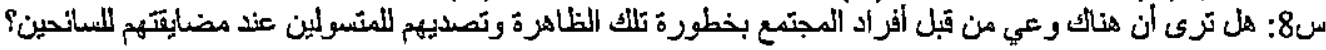

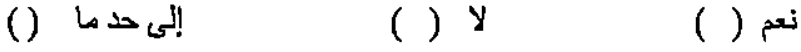

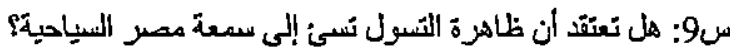

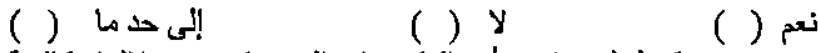

$$
\text { شكرأ على حسن تعارنكم }
$$

\section{The Begging as a Social Phenomenon and its Negative Impact on the Tourism Industry in Egypt}

The phenomenon of 'Begging' is one of the most serious social problems that face different contemporary societies, particularly in those suffering from economic crises such as poverty and unemployment. This phenomenon has been growing throughout the year and the number of beggars doubles in some seasons revealing the transformation of begging into a profession. Therefore it has become an epidemic prevailing in all societies without exception, but it has some differences in terms of its prevalence and severity from one community to another according to the customs, traditions and social levels existing in every society. This phenomenon leads to several negative impacts, whether social or economic or security, which also reflected on various fields of life, especially on the tourism field because of its extreme sensitivity, so all of us have to do our best in order to overcome this problem. The main objectives of this study are: highlighting the causes of the 'begging' phenomenon, analyzing the negative impacts of this phenomenon and how to overcome it. This study depends on two methods of collecting data: the theoretical Study: It depends on Arabic and English books, studies, periodicals, reports and official web sites. Also, the field Study: It depends on analyzing the responses of a questionnaire distributed to a sample of employees working in the some tourist areas in Cairo. The general conclusions of the study are: there is a relation between the begging phenomenon and the negative image of Egypt as a tourist destination, and the Tourist awareness is the best tool to face this phenomenon.

Keywords: Begging, Negative Impacts, Society, Tourism, Awareness 